This is an Open Access article, distributed under the terms of the Creative Commons Attribution licence (http://creativecommons.org/licenses/by/4.0/), which permits unrestricted re-use, distribution, and reproduction in any medium, provided the original work is properly cited.

\title{
More Than Just Zvejnieki: An Overview of Latvian Stone Age Burials
}

\author{
Auja Macāne ${ }^{1}$ @ and KerkKo Nordquist ${ }^{2}$ \\ ${ }^{1}$ Department of Historical Studies, University of Gothenburg, Sweden \\ ${ }^{2}$ Faculty of Arts, University of Helsinki, Finland
}

The well-known Zvejnieki cemetery, with 330 burials, is one of the largest hunter-gatherer cemeteries in northern Europe, overshadowing the more than 115 other Stone Age burials from over ten sites in Latvia. This article is a first overview of these other burials, summarizing their research history, characteristics, and assemblages. The authors discuss the problematic chronology of Latvian Stone Age burials and place them in a wider regional context. Most of the burials are hunter-gatherer burials, and a few are Corded Ware graves. This overview broadens our understanding of Latvian Stone Age burials and brings to light the diversity of hunter-fisher-gatherer mortuary practices in the eastern Baltic region.

Keywords: Stone Age, hunter-gatherers, mortuary practices, settlement site burials, crouched burials, Latvia

\section{INTRODUCTION}

Since its discovery in the 1960s, the Zvejnieki cemetery in northern Latvia has become a reference for hunter-gatherer burial archaeology. The current number of 330 excavated graves (Zagorskis, 1987, 2004; Larsson et al., 2017) makes it one of the largest burial grounds in northern Europe. Zvejnieki is exceptional not only for the quantity of recorded burials but also for their temporal span, from the eighth to the third millennium $\mathrm{BC}$ and beyond. Well-documented by the standards of the day, the burial practices reflected by the unusually well-preserved human bones and diverse material culture have been (and still are) widely studied and published, making Zvejnieki the showcase site of the Latvian Stone Age.

A considerable number of other Stone Age graves in present-day Latvia-over
115 individuals, from at least ten siteshave largely been overlooked. Often published in small fieldwork reports in Latvian or Russian, they remain relatively unknown to the international scientific community. The aim of the present article is to provide an overview of this little-discussed material and to discuss the chronology of Latvian Stone Age burials in detail. The funerary data are compared with research based on the Zvejnieki cemetery — which as mentioned above has historically dominated the discussion-and our observations are evaluated against northern Stone Age mortuary practices in their wider context. Such a study is necessary in light of other fundamental overviews recently carried out in other parts of the eastern Baltic region (Tõrv, 2018; Ahola, 2019; see also Butrimas, 2012). Furthermore, biomolecular and other archaeometric analyses, including on Latvian 
burial assemblages (Eriksson et al., 2003; Jones et al., 2017; Meadows et al., 2018), require a solid archaeological background.

The data relating to sites and burials are compiled in Table 1 and the online Supplementary Material. The traditional periodization of the Latvian Stone Age (e.g. Zagorska, 2006) is associated with blocks of archaeological cultures, defined in terms of culture history. The adoption of pottery marks the transition from the Mesolithic (9000-5400 BC) to the Neolithic (5400-1800 BC), the latter being traditionally divided into the Early (sixthfifth millennium $\mathrm{BC}$, epitomized by the Narva culture), Middle (Comb Ware culture, fourth millennium BC), and Late Neolithic (Corded Ware culture, third millennium BC). Here, we use absolute dates whenever possible, to avoid the problems caused by the variety of traditional chronological labels in different countries.

Most of the period under study is characterized by hunter-fisher-gatherer communities, with productive livelihoods only appearing in the context of the third-millennium $\mathrm{BC}$ Corded Ware culture. Consequently, the main focus is on hunter-gatherer burials. However, the line between hunter-gatherer and Corded Ware (or generally 'Late Neolithic') burials can become blurred: in past research they were often discussed together, and some hunter-gatherer burials have been interpreted as Corded Ware interments (Zagorskis, 1987; Loze, 2006a; see below). We have therefore included all Corded Ware burials in this article.

\section{A Brief History of Latvian Stone Age Burial Archaeology}

In 1827, a human skull accompanied by stone and antler implements was reported to have been found in Aizupe in western Latvia (Eberts, 1926: 4; Šturms, 1927a:
23) (Figure 1). However, the first documented Stone Age burials of the entire eastern Baltic region are those of Rin,nukalns by Lake Burtnieks in northern Latvia. The site was discovered in 1874 and investigated over the following decades (Sievers, 1875; Šturms, 1927b: 18) (Table 1). It remained the only known Stone Age burial site in Latvia until World War II, as even the fieldwork boom preceding the war (Šnore, 1938) revealed only inconclusive evidence of graves (see Šturms, 1946: 13).

Under post-war Soviet rule, construction projects began to reveal antiquities. A Stone Age burial ground was found during sand quarrying in Kreiči in southeastern Latvia and studied between 1955 and 1959 (Zagorskis, 1961) (Figure 2). A few more Stone Age burials were hastily investigated in 1967-68 in Jurkova, southeastern Latvia, before gravel extraction levelled its sandy hill, which also contained a medieval cemetery (Cimermane, 1968; Vankina \& Cimermane, 1969) (Figures 3 and 4). The Zvejnieki burial ground was similarly discovered in gravel extraction in the northern Lake Burtnieks area, and was investigated between 1964 and 1971 (Zagorskis, 1987, 2004).

Large-scale amelioration works in the Lake Lubāns region of eastern Latvia led to major landscape modifications and the discovery of a series of Stone Age sites (see Macāne, 2007). Between 1964 and 1971, at least sixty-one burials were investigated at the Abora I site (Loze, 1979: 43-52) (Figure 5). At Kvāpāni II, another fifteen graves were unearthed in 1977-78 (Loze, 1987a: 32-35, 2015: 40-43) (Figure 6), and three more burials were excavated at Upesgala licis in 1990 (Loze, 1992a). An individual burial was found in 1988 at the Iron Age site of Atkalni I near the present-day seaport of Liepāja (Petrenko \& Virse, 1990). In addition, numerous sites have, over the years, 
Table 1. Stone Age sites with confirmed burials and disarticulated human remains, as well as sites mentioned in the literature as potential Stone Age burial sites. Burial classes: 1 confirmed burials; 2 possible burials; 3 loose buman remains; 4 stray finds taken to indicate burials; 5 oral tradition of additional burials. Temporal classes: H hunter-gatherer; C Corded Ware; * sites with burials previously connected with the Late Neolithic and/or Corded Ware culture based on body position.

\begin{tabular}{|c|c|c|c|c|c|c|c|c|}
\hline Site & $\begin{array}{l}\text { Burial } \\
\text { class }\end{array}$ & $\begin{array}{l}\text { No. of } \\
\text { graves }\end{array}$ & $\begin{array}{l}\text { No. of } \\
\text { indiv. }\end{array}$ & $\begin{array}{l}\text { Temporal } \\
\text { class }\end{array}$ & Context & $\begin{array}{l}\text { Additional } \\
\text { information }\end{array}$ & Investigations & References \\
\hline Abora I & 1,3 & 46 & $61+$ & $\mathrm{H}^{*}$ & $\begin{array}{l}\text { Burials at a Middle-Late } \\
\text { Neolithic settlement, also } \\
\text { Bronze and Iron Age finds }\end{array}$ & $\begin{array}{l}\text { Many burials disturbed } \\
\text { by later land use (or } \\
\text { secondary burials?) }\end{array}$ & I. Loze 1964-65, 1970-71, 2008 & Loze, $1979,1987 \mathrm{~b}$ \\
\hline Atkalni I & 1 & 1 & 1 & $\mathrm{C}$ & $\begin{array}{l}\text { Solitary burial in a (Middle-) } \\
\text { Late Iron Age cemetery }\end{array}$ & & V. Petrenko \& I. Virse 1988 & $\begin{array}{l}\text { Petrenko \& Virse, } \\
\text { 1990; Loze, 2006a }\end{array}$ \\
\hline Iča & 3 & & & $\mathrm{H}^{*}$ ? C? & $\begin{array}{l}\text { Disarticulated bones from a } \\
\text { settlement occupied } \\
\text { throughout the Neolithic }\end{array}$ & & $\begin{array}{l}\text { E. Šturms 1938-39, F. Zagorskis } \\
\text { 1964, I. Loze 1988-89 }\end{array}$ & $\begin{array}{l}\text { Loze, 1979, 2006a, } \\
\qquad 2010\end{array}$ \\
\hline Jurkova & 1,3 & 4 & 7 & $\mathrm{H}$ & $\begin{array}{l}\text { Cemetery(?) at a medieval } \\
\text { site/cemetery }\end{array}$ & $\begin{array}{l}\text { Disturbed by later } \\
\text { land use; currently } \\
\text { destroyed }\end{array}$ & $\begin{array}{l}\text { I. Cimermane } 1967-68 \text {, } \\
\text { L. Vankina } 1968\end{array}$ & $\begin{array}{l}\text { Cimermane, 1968; } \\
\text { Vankina \& } \\
\text { Cimermane, } 1969\end{array}$ \\
\hline Kreiči & $1,3,5$ & 17 & $23+$ & $\mathrm{H}^{*}$ & $\begin{array}{l}\text { Cemetery next to a Middle(- } \\
\text { Late) Neolithic settlement, } \\
\text { also Bronze Age and later } \\
\text { finds }\end{array}$ & $\begin{array}{l}\text { Some burials disturbed } \\
\text { by later land use and } \\
\text { hydrological } \\
\text { fluctuations }\end{array}$ & $\begin{array}{l}\text { E. Šnore 1955, L. Vankina } \\
1956-57, \text { F. Zagorskis 1958- } \\
59\end{array}$ & Zagorskis, 1961, 1963 \\
\hline Kvāpāni II & 1,3 & 15 & 15 & $\mathrm{H}^{*}$ & $\begin{array}{l}\text { Burials at a settlement occu- } \\
\text { pied from the Late } \\
\text { Mesolithic to the Late } \\
\text { Neolithic, also Bronze Age, } \\
\text { Iron Age and medieval finds }\end{array}$ & $\begin{array}{l}\text { Many burials disturbed } \\
\text { by later land use (or } \\
\text { secondary burials?); } \\
\text { currently inundated }\end{array}$ & I. Loze 1974, 1976-79 & $\begin{array}{l}\text { Loze, 1979, 1987a, } \\
\quad 2015\end{array}$ \\
\hline Riņnukalns & 1,3 & 4 & $4+$ & $\mathrm{H}$ & $\begin{array}{l}\text { Burials at/under a Middle } \\
\text { Neolithic settlement/shell } \\
\text { midden, cut by a medieval- } \\
\text { early modern cemetery }\end{array}$ & $\begin{array}{l}\text { Largely disturbed by } \\
\text { later land use }\end{array}$ & $\begin{array}{l}\text { C.G. Sievers 1874-75, 1877; } \\
\text { A. Sommer 1881; K. von } \\
\text { Löwis of Menar 1895; } \\
\text { M. Ebert 1913; E. Šturms } \\
\text { 1943; V. Bērziňš et al., 2009- } \\
\text { 11, 2017-18 }\end{array}$ & $\begin{array}{l}\text { Sievers, 1875; Šturms, } \\
\text { 1927b; Bērziňš et al., } \\
\text { 2014; Lübke et al., } \\
\text { 2016; Brinker et al., } \\
\text { 2020 }\end{array}$ \\
\hline Sarkani i & 1 & 1 & 1 & $\mathrm{C}$ & Solitary burial & $\begin{array}{l}\text { Originally excavated } \\
\text { by local landowner } \\
\text { (1973); site is also } \\
\text { called Lake Sedzers }\end{array}$ & N. Grasis 1994 & $\begin{array}{l}\text { Grasis, 1996; Loze, } \\
\text { 2006a }\end{array}$ \\
\hline
\end{tabular}


Table 1. (Cont.)

\begin{tabular}{|c|c|c|c|c|c|c|c|c|}
\hline Site & $\begin{array}{l}\text { Burial } \\
\text { class }\end{array}$ & $\begin{array}{l}\text { No. of } \\
\text { graves }\end{array}$ & $\begin{array}{l}\text { No. of } \\
\text { indiv. }\end{array}$ & $\begin{array}{l}\text { Temporal } \\
\text { class }\end{array}$ & Context & $\begin{array}{l}\text { Additional } \\
\text { information }\end{array}$ & Investigations & References \\
\hline Sārnate & 3 & & & $\mathrm{H}$ ? & $\begin{array}{l}\text { Disarticulated bones from a } \\
\text { settlement occupied } \\
\text { throughout the Neolithic }\end{array}$ & & $\begin{array}{l}\text { E. Šturms 1938-40; L. Vankina } \\
\text { 1949, 1953-59 }\end{array}$ & Bērziņš, 2008 \\
\hline Selgas & 1 & 1 & 2 & $\mathrm{C}$ & Solitary burial & $\begin{array}{l}\text { Originally excavated } \\
\text { by local landowner } \\
\text { (1994) }\end{array}$ & N. Grasis 1994 & Grasis, 1996, 2007 \\
\hline $\begin{array}{l}\text { Upesgala } \\
\text { līcis }\end{array}$ & 1 & 3 & 3 & $\mathrm{H}$ & $\begin{array}{l}\text { Burials at a Middle Neolithic } \\
\text { settlement, also Iron Age } \\
\text { finds }\end{array}$ & Also called Iča II & I. Loze 1965, 1990 & Loze, 1992a \\
\hline Vendzavas & 1,3 & 1 & 1 & $\mathrm{H}$ & $\begin{array}{l}\text { Solitary burial next to/in a } \\
\text { Late Mesolithic settlement }\end{array}$ & $\begin{array}{l}\text { Partly disturbed by } \\
\text { later land use }\end{array}$ & V. Bērziņš 1995-96, 1998 & Bērziņš, 2002 \\
\hline Zvejnieki & $1,3,5$ & 330 & $342+$ & $\mathrm{H}^{*}, \mathrm{C}$ & $\begin{array}{l}\text { Cemetery near Mesolithic and } \\
\text { Neolithic settlements, also } \\
\text { Bronze Age, Iron Age and } \\
\text { medieval burials }\end{array}$ & $\begin{array}{l}\text { Partly disturbed by } \\
\text { later land use }\end{array}$ & $\begin{array}{l}\text { F. Zagorskis 1964-66, 1968, } \\
\text { 1970-71; I. Zagorska et al., } \\
\text { 2005-09, } 2014\end{array}$ & $\begin{array}{l}\text { Zagorskis, 1987, 2004; } \\
\text { Zagorska, 2006; } \\
\text { Larsson et al., } 2017\end{array}$ \\
\hline \multicolumn{9}{|l|}{-} \\
\hline Aizupe & 4 & & & $\mathrm{C}$ ? & Stray find & & & $\begin{array}{l}\text { Šturms, 1927a; Loze, } \\
\text { 1987b }\end{array}$ \\
\hline Andrini & 4 & & & C? & Stray find & & & $\begin{array}{l}\text { Šturms, 1970; Loze, } \\
\quad 1987 b\end{array}$ \\
\hline Bāḷas & 2 & 2 & 2 & $\mathrm{H}^{*}$ ? C? & $\begin{array}{l}\text { Burials in a Middle-Late Iron } \\
\text { Age cemetery }\end{array}$ & & F. Ozoliņš 1926 & $\begin{array}{l}\text { Ozolinšs, 1926; Grasis, } \\
2007\end{array}$ \\
\hline Grīnerti & 2 & 2 & 2 & $\mathrm{H}^{*}$ ? C? & $\begin{array}{l}\text { Burials in a Middle-Late Iron } \\
\text { Age cemetery }\end{array}$ & $\begin{array}{l}\text { Also called Zvārdes } \\
\text { Grīnerti }\end{array}$ & E. Šnore 1935 & $\begin{array}{l}\text { Šnore, 1935; Loze, } \\
\text { 1987b }\end{array}$ \\
\hline Kandava & 4 & & & C? & Stray find & & & $\begin{array}{l}\text { Šturms, 1970; Loze, } \\
\quad 1987 b\end{array}$ \\
\hline Ķ̄īšzers & 4 & & & $\mathrm{C}$ ? & Stray find & & & Loze, 1997 \\
\hline Krīgāni & 2,3 & 4 & 4 & $\mathrm{H}^{*}$ ? C? & $\begin{array}{l}\text { Burials in a Middle-Late Iron } \\
\text { Age settlement and } \\
\text { destroyed Late Neolithic- } \\
\text { Bronze Age site(?) }\end{array}$ & & A. Stubavs 1978-79 & $\begin{array}{l}\text { Stubavs, 1980; Loze, } \\
\text { 1987b }\end{array}$ \\
\hline
\end{tabular}



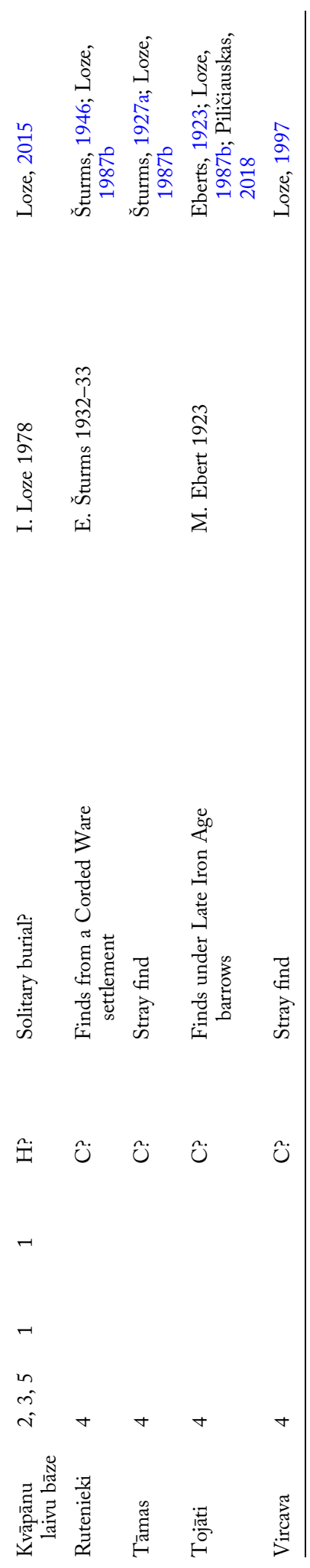

yielded undated burials and disarticulated human bones (Stubavs, 1980; Bērziñš, 2008: 337; Loze, 2010: 94).

The first studies of Stone Age interments after the collapse of the Soviet Union were undertaken in 1994, when two Corded Ware burials, both originally dug up by local landowners, were investigated in Sarkani in eastern Latvia and in Selgas on the Lithuanian border (Grasis, 1996, 2007). In 1998, a burial was excavated at the Mesolithic settlement of Vendzavas on the Latvian seacoast (Bērziñš, 2002).

A new phase of burial archaeology started in the 2000s through an international research collaboration, with a Latvian-Swedish project that investigated further burials at the Zvejnieki cemetery between 2005 and 2009 (Larsson, 2010; Nilsson Stutz et al., 2013; Larsson et al., 2017). New finds of human remains were also made by the Latvian-German cooperative project at the Rinnukalns site in 2011-2018 (Bērziñš et al., 2014; Lübke et al., 2016; Brinker et al., 2020).

\section{The Material and its Classification}

The main sources for this study consist of Stone Age burials excavated in Latvia, excluding Zvejnieki. All the relevant literature was reviewed, and an archival study of the available reports and related documentation undertaken at the Repository of Archaeological Material, Institute of Latvian History at the University of Latvia in Riga. Finds present in the collections and permanent exhibition of the National History Museum of Latvia (Riga) and the Liepaja Museum were examined. Human osteological material was not investigated; all osteological information (see online Supplementary Material) was taken from publications.

The level of documentation often makes evaluating the finds and contexts difficult. 


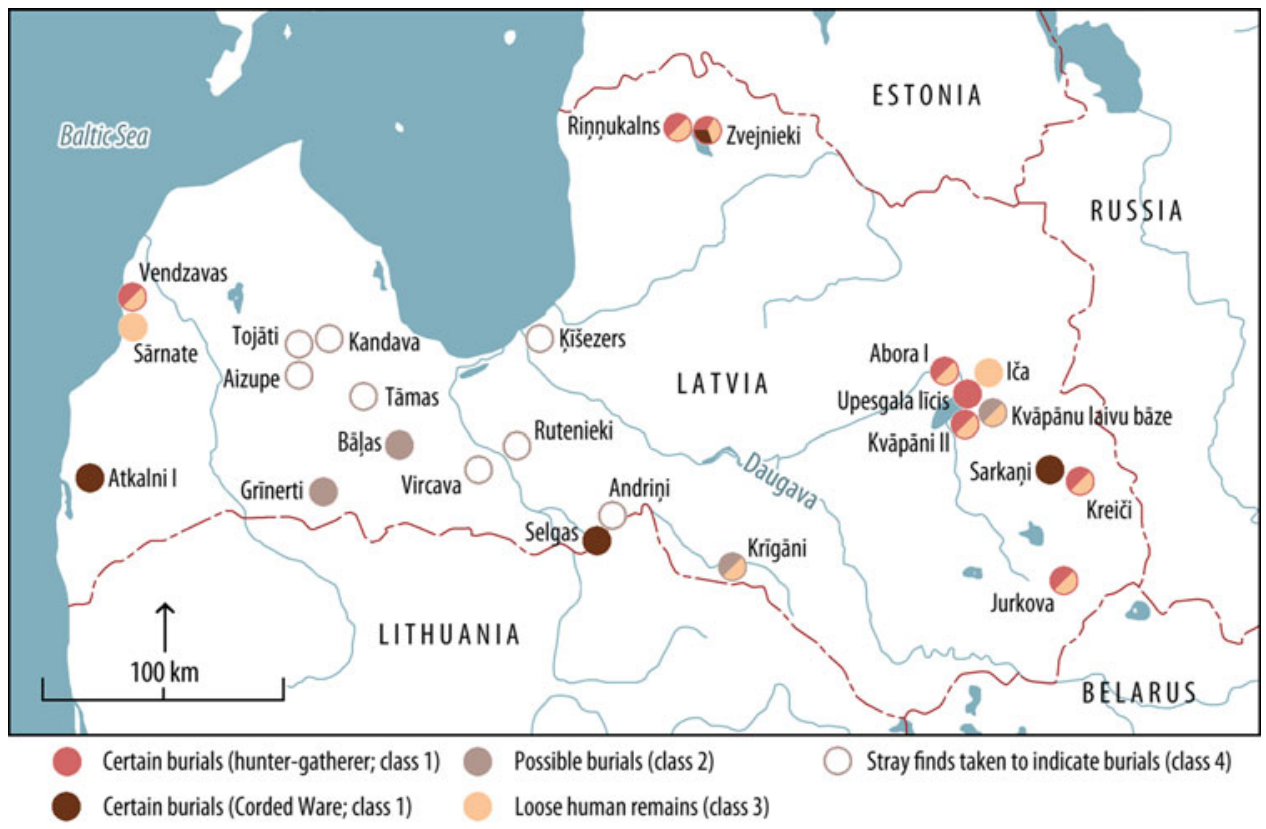

Figure 1. Latvian Stone Age burial sites and possible locations mentioned in the text.

Decades ago, shovels were used but no sieving took place, and many excavations were rescue excavations with limited resources. In Soviet times, local enthusiasts or school children were frequently employed as labour; professional archaeologists were few and primarily oversaw the works. Consequently, descriptions of individual burials can be extremely sketchy, and site plans, drawings, and photographs are often missing. Particular problems, especially in the Lake Lubāns area, arise from discrepancies in the field reports and subsequent publications. These contradictions have been tracked by consulting the primary documentation whenever possible.

The burials appearing in publications and reports have been divided into five classes (Table 1 and online Supplementary Material). Class 1 includes secure burials containing confirmed human remains with diagnostic artefacts; burials without grave goods, but located within a Stone Age site amidst definite burials, are also included in this category. Our article will mainly focus on these burials. Class 2 refers to possible burials, i.e. human remains discovered during archaeological excavations but without grave goods and located at sites dating to later periods; these may be of the Stone Age date, according to their body position and/or adjacent (stray) Stone Age finds. Class 3 includes disarticulated human remains found in Stone Age settlement layers; it is not possible to verify whether they derive from destroyed inhumations or represent alternative ways of body disposal. Class 4 covers the Corded Ware-related artefacts mentioned in the literature as representative of burials (especially Šturms, 1970: 285; Loze, 1992b, 1997, 2006a), although their burial status is generally hypothetical. Class 5 consists of oral evidence, i.e. burials allegedly found by the public before investigation by an archaeologist.

Chronology presents a challenge, since most burials lack typologically dateable grave goods and radiocarbon dates (see below). Given 'persistent practices' (Tõrv, 


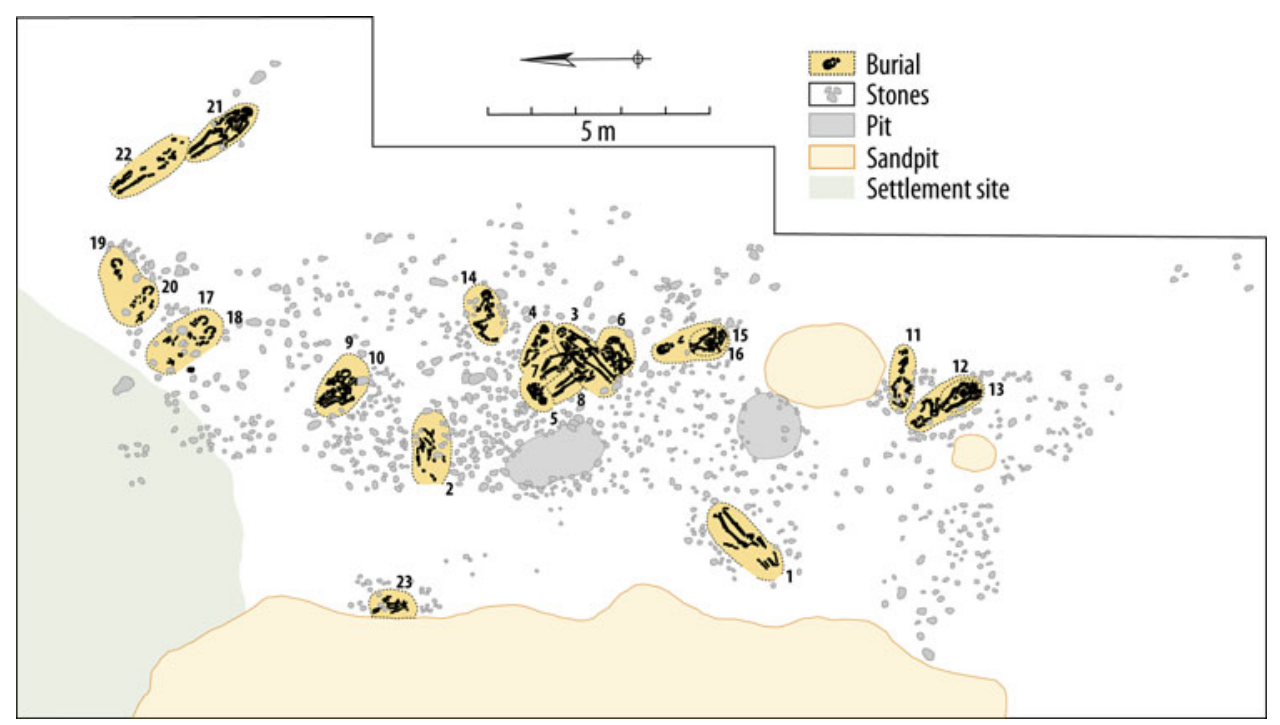

Figure 2. Plan of the Kreĩci site (after Zagorskis, 1961: fig. 2).

2018; see below), individual hunter-gatherer burials are difficult to date accurately from burial customs alone. We therefore employ a simple division into hunter-gatherer and Corded Ware burials here. Unlike many previous accounts, where body position alone was considered sufficient to associate a burial with the Late Neolithic and/or Corded Ware culture, here we have retained only secure burials with Corded Ware-related grave goods (such as battle axes or other axe types, Corded Ware pottery, flint knives or tools, bone and antler plaques, awls, or tools) and burial customs (mainly single inhumations in a crouched or supine position with bent legs). Only three graves belong to this category, the remaining burials are labelled as those of hunter-gatherers.

\section{Burial Practices in Stone Age Latvia}

\section{Burial characteristics}

The burials are flat graves. When (oval/ round) burial pits are identifiable, the size of the single burials varies from $c .0 .5 \times 1 \mathrm{~m}$ to $1 \times 2 \mathrm{~m}$; double and multiple burials are slightly larger, up to $1 \times 2.5 \mathrm{~m}$ (see online Supplementary Material). The pits of Corded Ware burials seem to be larger than those of the hunter-gatherers, although they are disturbed and generally too few to draw conclusions. Nonetheless this is in line with data from neighbouring areas, which suggest that hunter-gatherer burials more closely followed the physical dimensions of the buried bodies (Ahola \& Heyd, 2020: 84).

The Corded Ware burials are also deeper, being $0.9-1.4 \mathrm{~m}$ deep, whereas the hunter-gatherer graves range between 0.2 and $0.9 \mathrm{~m}$ in depth, with an average of $0.5 \mathrm{~m}$. The shallowness of some graves has sometimes been interpreted as some hunter-gatherer burials being originally placed on the surface of the ground and covered with soil (Kreiči: Zagorskis, 1961: 8; Kvāpāni II: Loze, 2008a: 12). Similar suggestions have been made concerning some burials in the hunter-gatherer cemetery of Sakhtysh IIa in central Russia (Kostyleva \& Utkin, 2010: 41), but none 

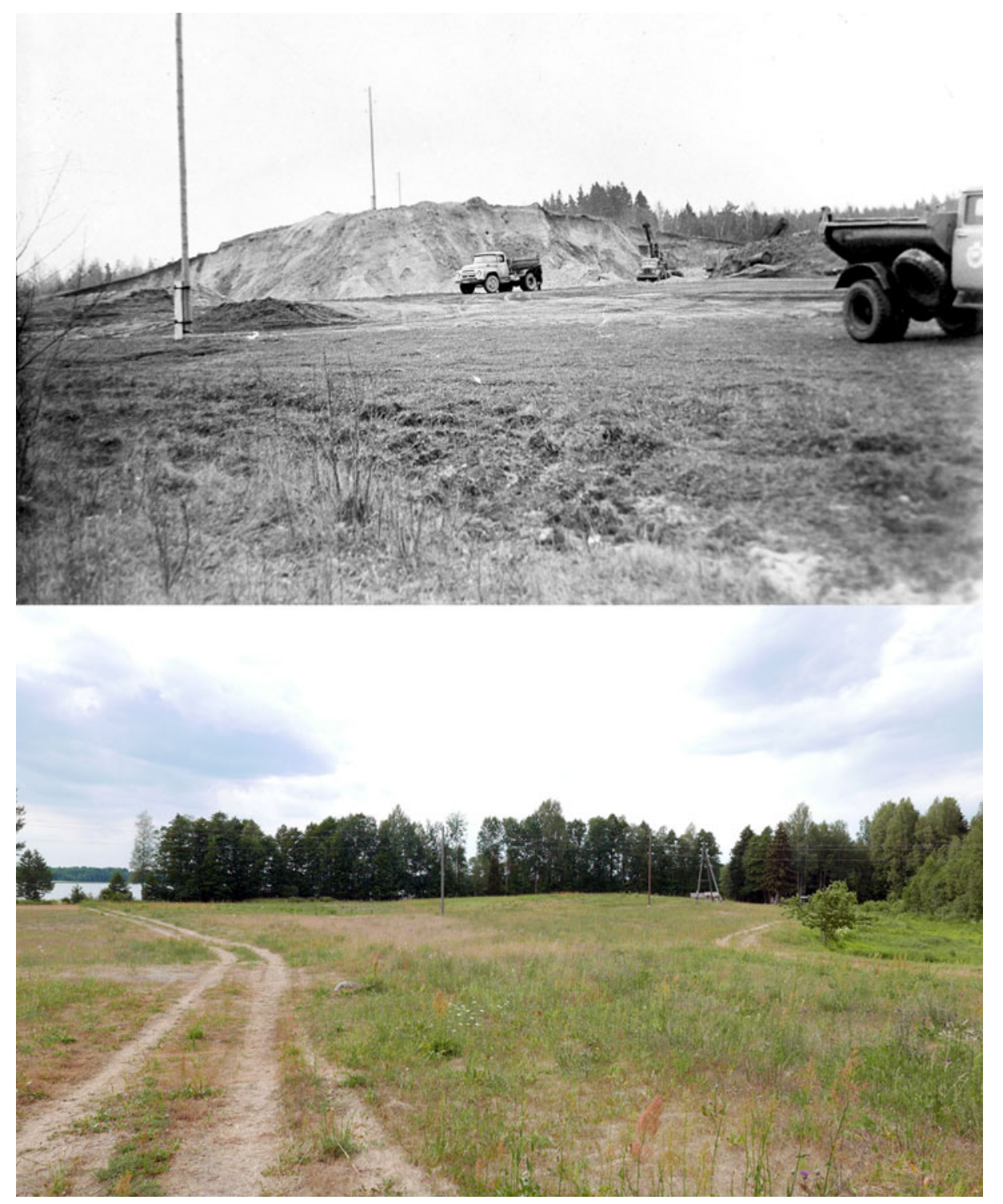

Figure 3. Jurkova: modern exploitation revealing archaeological sites but also destroying the environment and cultural heritage. The illustration shows the site in 1967 (above; photograph in Cimermane, 1967: 15) and the area in 2019, with the hill removed (below). Top photograph by permission of the Repository of Archaeological Material, Institute of Latvian History at the University of Latvia (VIAA 205:15).

of these suggestions can be confirmed by the available documentation.

Despite undefined grave cuts, often poorly preserved skeletons, and later disturbances, the orientation of most huntergatherer burials has been approximated.
The heads are oriented most often towards the north, the east, and the south-east, but there are significant variations between sites: for example, the bodies in Abora I are often buried with the heads towards the north, the south, or 


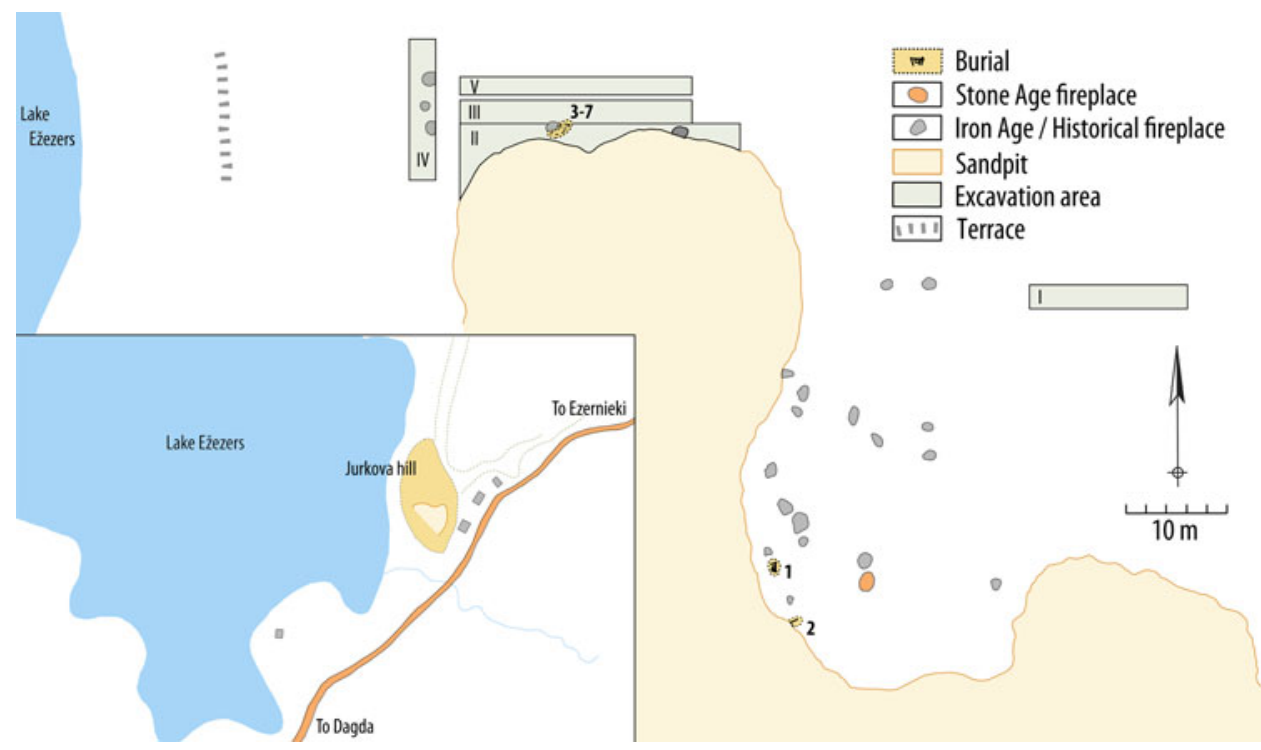

Figure 4. Map and plan of the Jurkova site (after maps in Cimermane, 1967 and Vankina, 1968).
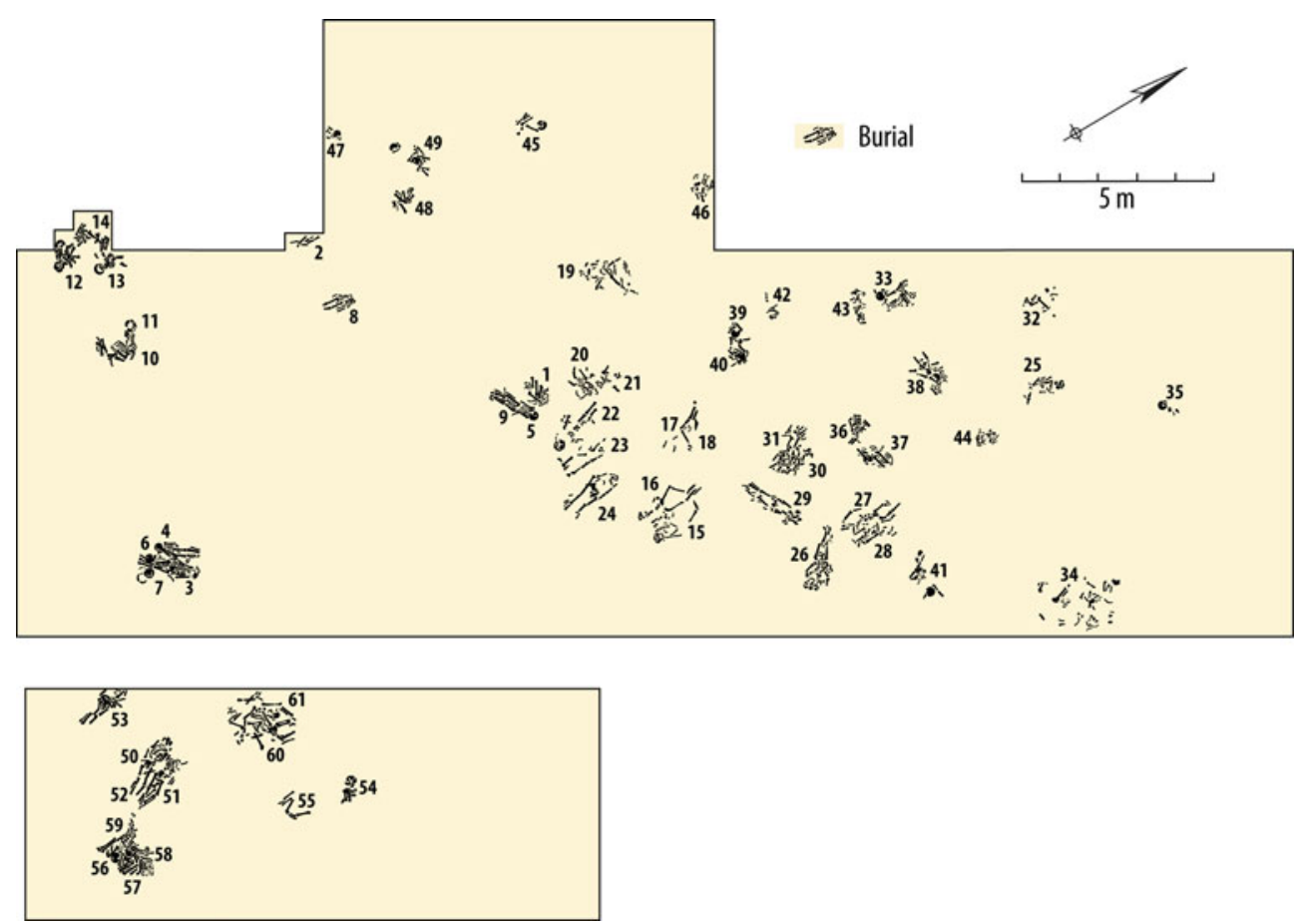

Figure 5. Plan of the Abora I site (after Loze, 1979: fig. 38).

the south-west, while in Kreiči the heads influencing orientation) cannot be found, are oriented to the south-east. Simple and varying orientations are also characterexplanations (e.g. the local terrain istic of burials in Zvejnieki (Zagorskis, 

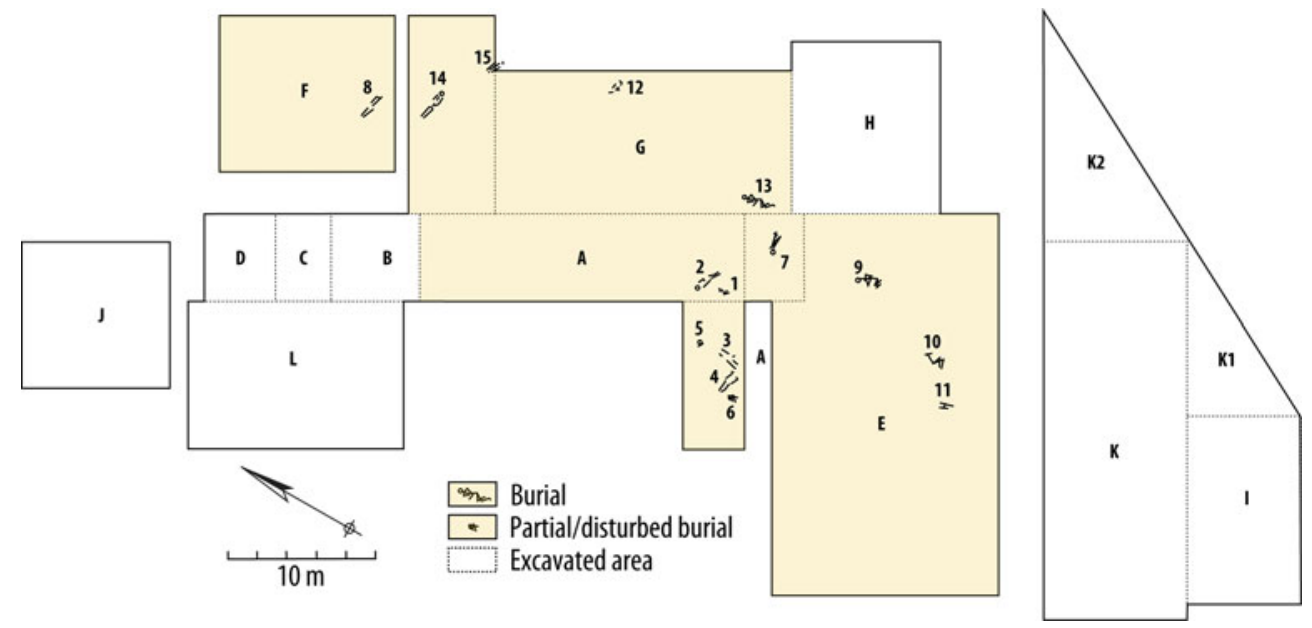

Figure 6. Plan of the Kvāpanni II site (after Loze, 1987a: fig. 5, 2015: fig. 12).

1987: 94; Zagorska, 2016: 229) and surrounding regions (Larsson, 1988: 104; Kostyleva \& Utkin, 2010: 251-59; Butrimas, 2012: 152; Tõrv, 2018: tab. 13). Corded Ware graves seem to follow an east-west axis, which is typical of this type of burial (e.g. Ahola \& Heyd, 2020: 84).

\section{Body position and treatment}

More than half the hunter-gatherer inhumations were in a supine position. Even including positions inferred from disturbed and incomplete skeletons, one-third of body positions remains unknown. We know of nineteen crouched and supine burials with bent legs, three prone burials, and six (half-)sitting (Figure 7). Extended supine and flexed positions are also the most common in many other northern hunter-gatherer burial sites (e.g. Butrimas, 2012: 151; Brinch Petersen, 2015: 90; Tõrv, 2018: fig. 80). Prone burials are encountered only occasionally (Zagorskis, 1987: 23; Larsson, 1988: 114; Kostyleva \& Utkin, 2010: 253, 256; Ahola et al., 2020: 51), and the unexpectedly frequent (half-)sitting burials have some parallels in the Baltic Sea region (Larsson, 1988: 107; Nilsson, 2007: 45; Butrimas, 2012: 151; Bugajska, 2015: 11; Grünberg, 2016: 16), although none is known at Zvejnieki.

Three-quarters of the burials are single inhumations, but some double burials are known, especially at Kreiči, and multiple burials have been recorded particularly at Abora I (four persons maximum). The body positions are usually, but not always, the same for all individuals in one grave; the orientations are either the same or opposing. Infants and children, as well as the deceased placed in a (half-) sitting position, often form part of double or multiple burials (Figure 7).

In a few cases (Abora I), the multiple burials may be the result of later mixing, which unfortunately can no longer be determined. In most cases, it is similarly impossible to evaluate whether partial skeletal remains result from post-burial body modification or later destruction (including loose bones found in settlements). Occasionally (at Abora I, Kvāpāni II), the remains are probably secondary depositions of disarticulated bones, but once again the lack of documentation prevents further study (see Nilsson Stutz, 2006; 


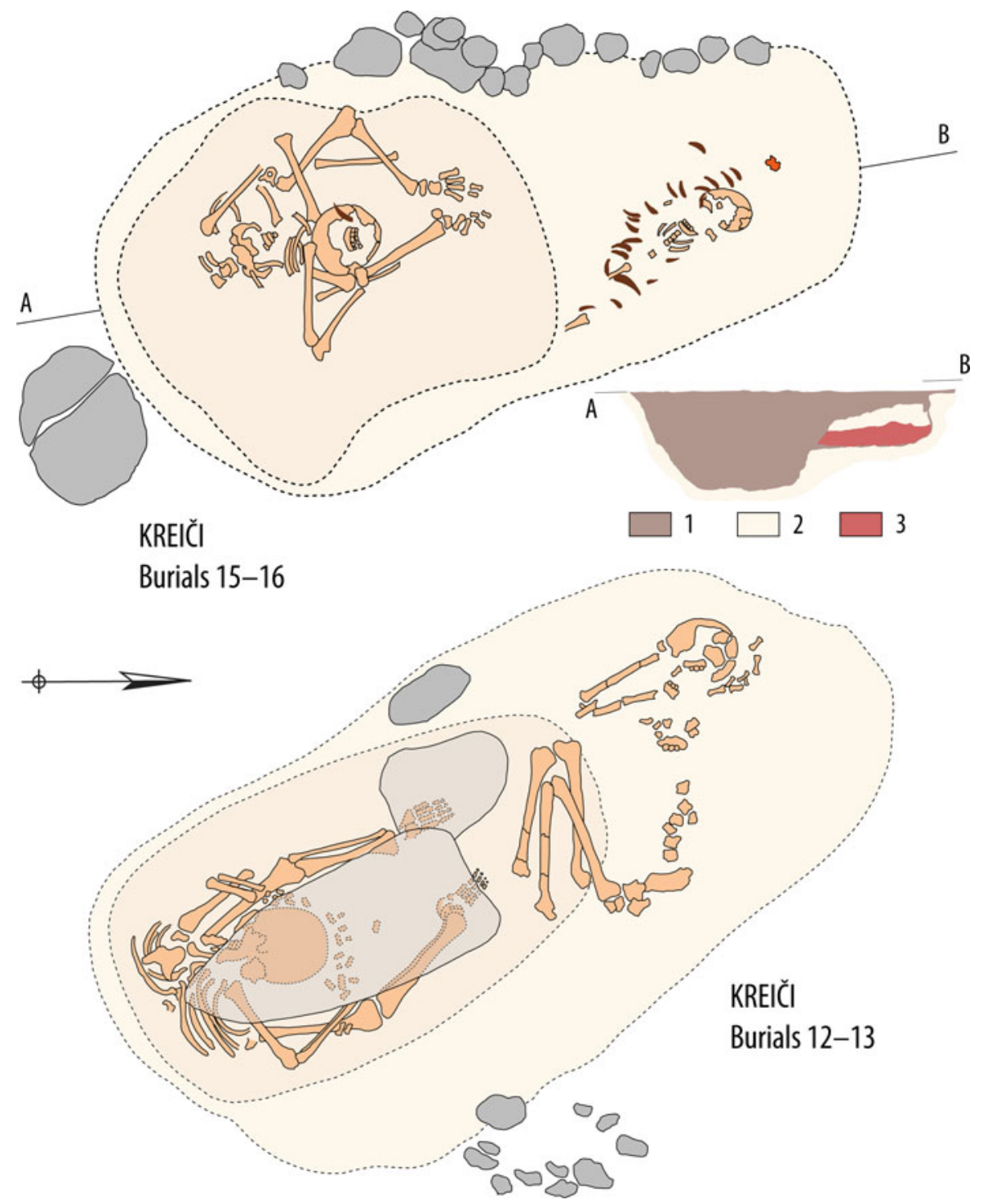

Figure 7. Burials in (half-)sitting position. Top: woman and child with red ochre (Kreici burials 15 and 16). Bottom: male(?) buried under large stones and accompanied by a crouched male (Kreici burials 12 and 13). Key: 1: dark soil; 2: clayey sand; 3: red ochre. Not to scale (after Zagorskis, 1961: figs. 5 and 7).

Tõrv, 2018). It also appears that several burials are missing or consist only of a skull (Abora I, Kreiči, Kvāpāni II); the manipulation of skulls is a fairly common trait among hunter-gatherer inhumations (Zagorskis, 1987: 93; Kostyleva \& Utkin, 2010: 259; Butrimas, 2012: 151; Brinch
Petersen, 2016: 59; see also Gummesson et al., 2018: 85). Modification of the cadaver has been proposed in the case of the unnatural position of the Vendzavas burial (Bērzinšs, 2002: 33), and some prone or heavily flexed individuals (Kreiči: Zagorskis, 1961: 6, 9; Kvāpāni II: Loze, 
1979: 53) are thought to indicate that the body was wrapped or bound, representing burial practices well-attested in Zvejnieki and several other sites in northern Europe and Russia (Nilsson Stutz, 2006: 230; Kostyleva \& Utkin, 2010: 251; Bugajska, 2015: 20; Tõrv, 2018: 188).

Corded Ware burials are of single bodies (at Selgas a woman was buried with a child), in crouched or supine position with bent legs, as described in our definition of Corded Ware burial. They resemble the Corded Ware burials found elsewhere in the eastern Baltic, including Zvejnieki (Kriiska \& Tvauri, 2002: 81; Zagorska, 2006: 103; Piličiauskas, 2018: 119).

\section{Internal grave structure}

The simple primary pits of the huntergatherer graves are seldom accompanied by clearly identifiable internal or covering structures. Various stone settings, packings, and frames are present in Kreiči (Figure 7); the site lies on morainic terrain, and single stones have also occasionally been placed in burials at Abora I, Jurkova, Kvāpāni II, and Riņnukalns. Stones and stone settings, either underlaying or covering the burials, are also known at Zvejnieki (Zagorskis, 1987: 88; Zagorska, 2016: 231) and other huntergatherer burial sites in stone-rich areas, such as southern Scandinavia and Finland (Brinch Petersen, 2015: 101; Larsson, 2016: 178; Ahola, 2019: 45-47).

Organic materials related to the burial are recognized and recorded even more rarely. In Vendzavas, the deceased was covered with material that may have been bark (Bērzinšs, 2002: 34). The use of wooden containers for some of the dead has been proposed at Abora I (Loze, 1987b: 6-7, 2008b: 119), but this interpretation is based on highly insecure evidence (a piece of wood and a posthole). Organic inner components (wood, bark, basketry, etc.), used either as platforms, coverings, or containers, are not reported from Zvejnieki, even though they are known from numerous hunter-gatherer burials elsewhere in the Baltic region (Brinch Petersen, 2015: 90, 101; Bugajska, 2015: 20-21; Larsson, 2016: 178-79; Ahola, 2019: 47).

Red ochre is found only in a few graves in Jurkova and Kreiči (Figure 7). Although mentioned as the most important symbolic feature of hunter-gatherer burials (e.g. Zagorska, 2016: 236), ochre is often missing from northern European and Russian graves (Kostyleva \& Utkin, 2010: tabs. 15 and 16; Tõrv, 2018: 170; Ahola, 2019: 20), and is absent from nearly half the Zvejnieki burials (Zagorska, 2008: 117). Traces of fire and charcoal, charcoal spreads, or pits are reported from a few graves in Jurkova, Kreiči, and Rinnnukalns. Hearths are also sometimes recorded on other northern burial sites (Larsson, 1988: 114-15; Kostyleva \& Utkin, 2010: 256; Butrimas, 2012: 156; Ahola, 2019: appendix 1), but are not present in Zvejnieki. Features interpreted as cremations, while on rare occasions present in hunter-gatherer contexts elsewhere (Brinch Petersen \& Meiklejohn, 2003; Grünberg, 2016: 14; Larsson, 2016: 179; Ahola, 2019: 60), are not reported from Latvia.

Small pits filled with occupation material derived from a cultural layer have been found in burials in Kreiči and Upesgala licis. The use of such material (from an adjacent settlement) as grave fills is a common feature in Kreiči. A similar intentional use of particular soils as part of burial practices is also described in Zvejnieki (Zagorskis, 1987: 92, 97; Larsson et al., 2017: 86) and other cemeteries, for example in Sweden and Finland (Larsson, 2016: 180; Ahola, 2019: 64-65). 
No clear internal structures or covering mounds were recorded for the Corded Ware graves. This lack, or simplicity, of covering and internal structures is a feature characteristic of the eastern Baltic and Finnish Corded Ware burials in general (Piličiauskas, 2018: 119; Ahola \& Heyd, 2020, 83-84).

\section{Grave goods}

The presence and quantity of grave goods vary considerably between sites and burials, but they are generally few: almost two-thirds of burials have no grave goods. Only in Kreiči are more than half of the deceased provided with artefacts, although Abora I and Jurkova also contain some wealthier burials (Figure 8). Usually a maximum of five items are present (almost seventy-five per cent of the burials with finds), and both men and women, young and old, may be buried with grave goods.

The frequency of grave goods and content of the assemblages correspond to the situation in other adjacent major hunter-gatherer burial sites, including Zvejnieki. Animal tooth pendants, including unworked teeth, constitute almost half the grave goods. Usually one or two pendants are found in a burial, although the richest graves contained forty-six (Kreiči burial 15) and twenty (Kreiči burial 6) such artefacts (Figure 9). Teeth from numerous species (wild boar, elk, red deer, aurochs, bear, dog, beaver) provided the raw material for the pendants.

Amber ornaments comprise some thirty per cent of the finds, but over seventy per cent of these come from Abora I, a site with major amber workshops nearby (Loze, 2008b). Only here is amber more frequent than tooth pendants; at other sites amber consists of mostly isolated finds, if at all present. Amber is represented by various buttons and pendants, tubular beads, perforated plates, and irregular pieces (Figure 9). Precise information about the location of individual grave goods in the burials is often missing, with the exception of Kreiči. The location of amber ornaments (like that of animal tooth pendants) on and around the head, upper body, and limbs indicates that they were used as ornaments or amulets worn on the body or sewn onto clothing or wrappings.

Lithic items are relatively rare (some seven per cent) and consist mostly of flint (and some slate) flakes, small tools, and arrowheads. The remaining grave goods are made of bone and antler ( $c$. fifteen per cent), including pendants and beads, tools, arrowheads, and some worked and unmodified pieces. In addition, abundant fish remains were discovered in connection with some burials in Riņnukalns and Abora I (see Larsson, 1988: 145; Brinch Petersen, 2015: 101 for Scandinavian parallels).

Ceramic vessels are generally not found in the funerary assemblages of huntergatherers in northern Europe and Russia (Zagorskis, 1987: 78; Ahola, 2019: 57). Most pottery fragments (as well as lithics and small animal bones) in the graves are interpreted as deriving from the cultural layer used to fill the graves. While the focus has usually been on 'formal' goods placed in burials, it is possible that some of these fragments may have been deliberately deposited (Ahola, 2017: 210; Larsson et al., 2017: 85; Brinker et al., 2020: 5). A few ceramic sherds are known from two pits found under the deceased in Upesgala līcis and Kreiči.

As our definition suggests, finds are present in all the Corded Ware burials, and consist of stone (battle) axes, pottery, flint and bone tools, and ornaments (Figure 10). These assemblages parallel the finds usually encountered in Corded Ware burials elsewhere in the eastern Baltic (Kriiska \& 


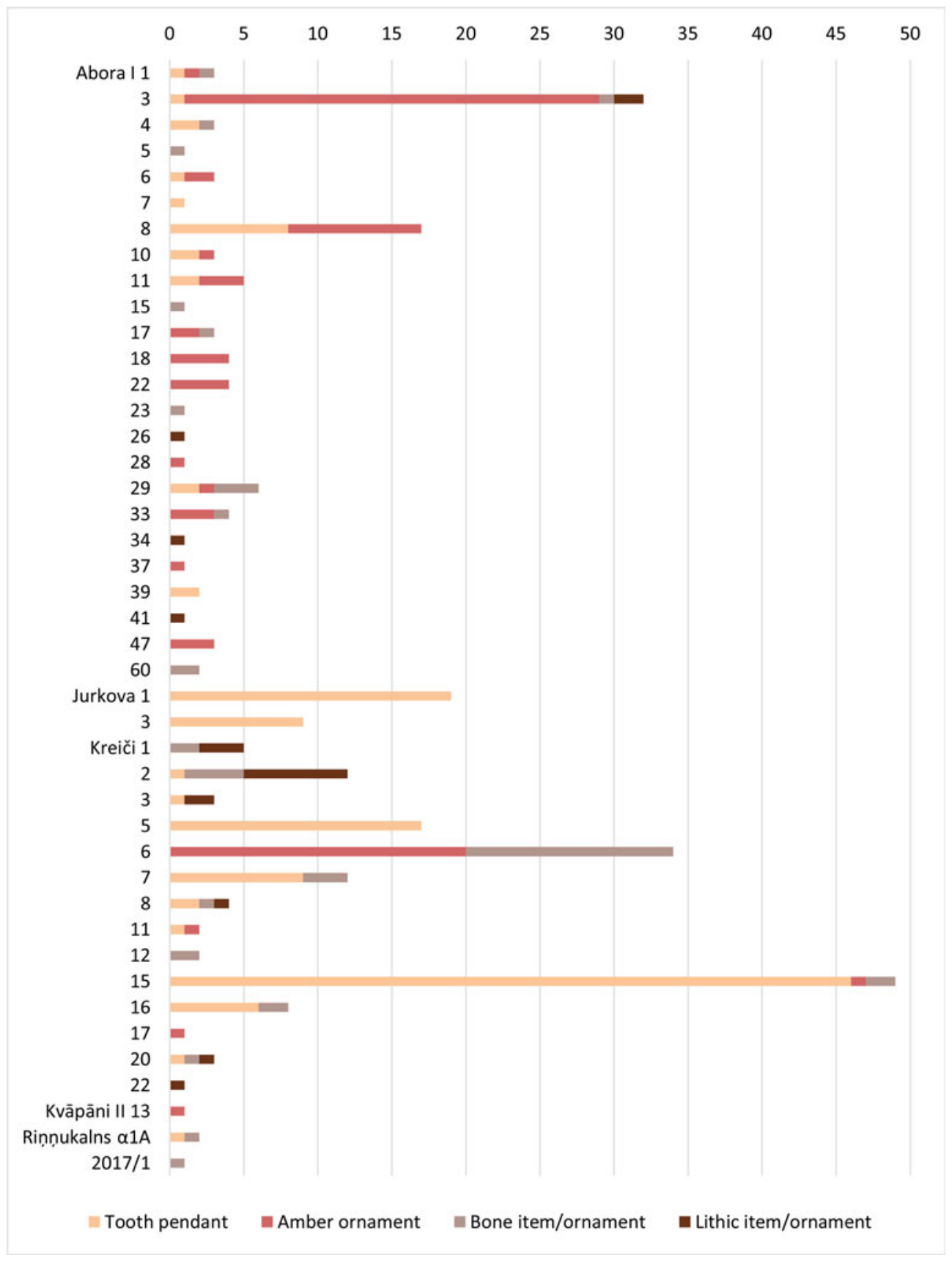

Figure 8. Assemblages present in Latvian hunter-gatherer burials (excluding Zvejnieki).

Tvauri, 2002: 81; Piličiauskas, 2018: 119; Ahola \& Heyd, 2020: 86-87), including Zvejnieki (Zagorskis, 1987: 78; Loze, 1997: 139-40).

\section{Discussion}

Absolute chronology is one of the challenges that Latvian burial archaeology 


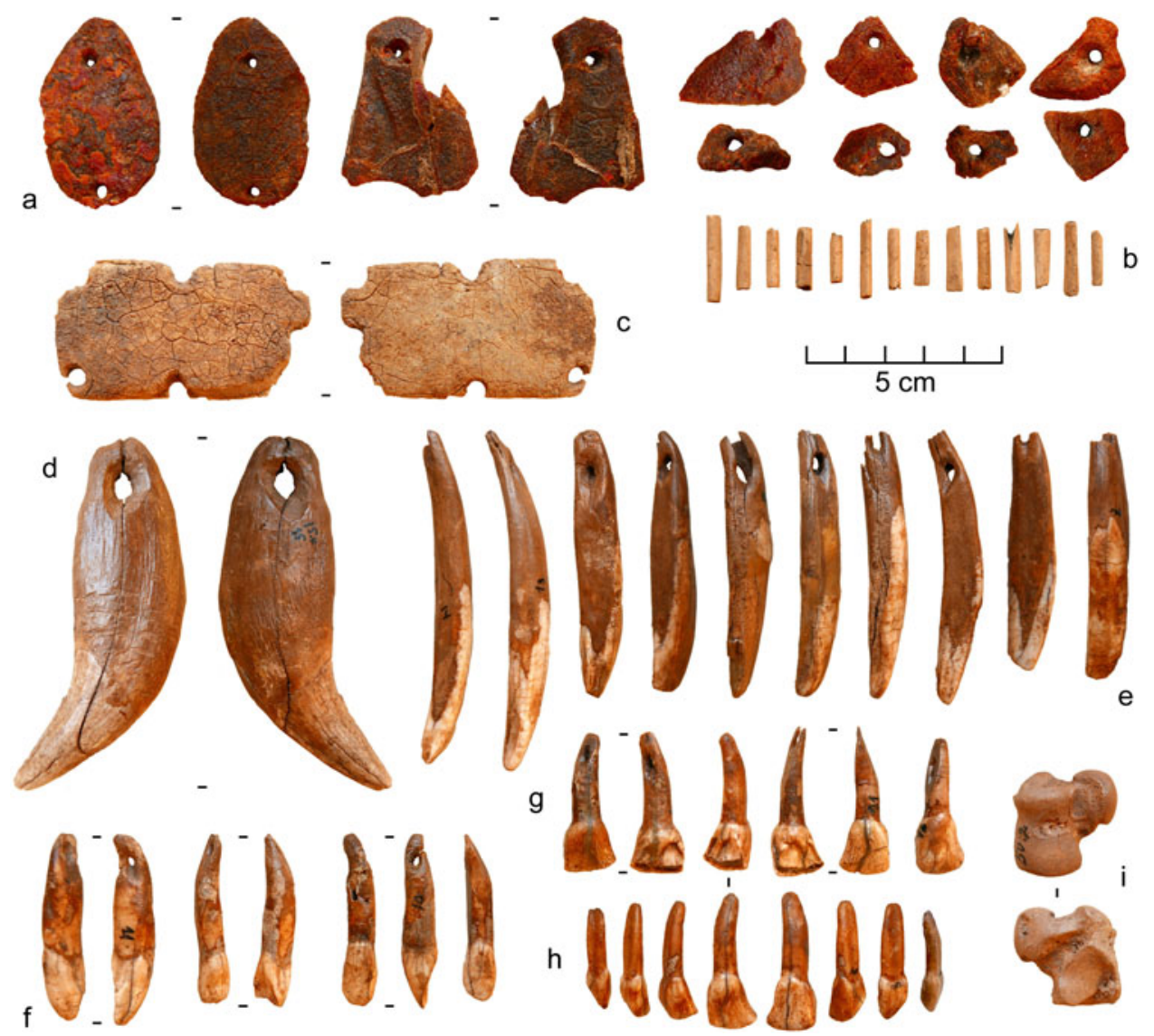

Figure 9. Grave goods from Kreici. Burial 6 contained twenty amber pendants (a) and fourteen tubular bone beads (b); Burial 15 (see Figure 7) had an amber plate (c) and forty-three animal tooth pendants (d: bear; e: wild boar; $f:$ elk, and g: red deer including $h$ : a full set of unperforated teeth from a single mandibula) and animal bones (i: beaver astragalus). By permission of the Department of Archaeology, National History Museum of Latvia (LNVM VI:35).

faces. The only adequately dated sites are Zvejnieki (Zagorska \& Larsson, 1994; Eriksson et al., 2003; Larsson, 2010; Zagorska et al., 2018) and Rinnukalns (Bērziñš et al., 2014; Lübke et al., 2016; Brinker et al., 2020). The former site spans an exceptionally long period, between the late eighth and third millennium $\mathrm{BC}$ (and beyond), and the latter dates to the later fourth millennium BC. Radiocarbon studies have shown that the freshwater reservoir effect may be substantial (up to almost a millennium; Meadows et al., 2014: 829, 2016: 688), and must be taken into account when dating samples from present-day Latvia.

Individual dates of human bones from Selgas (Ua-19802, 4165 \pm 60 BP) and Sarkani (Ua-19801, 4285 \pm 75 BP; Eriksson et al., 2003: tab. 3), assumed to be free of the reservoir effect (Meadows et al., 2018: 1002), agree with the age of their Corded Ware assemblages. The dating of a human bone from burial 2 in Kvāpāni II (GIN6299, 5250 \pm 200 вP; Loze, 2008a: 12) is of little use, given the wide error margin and unknown reservoir offset. The dates of charcoal, wood, and peat from different 

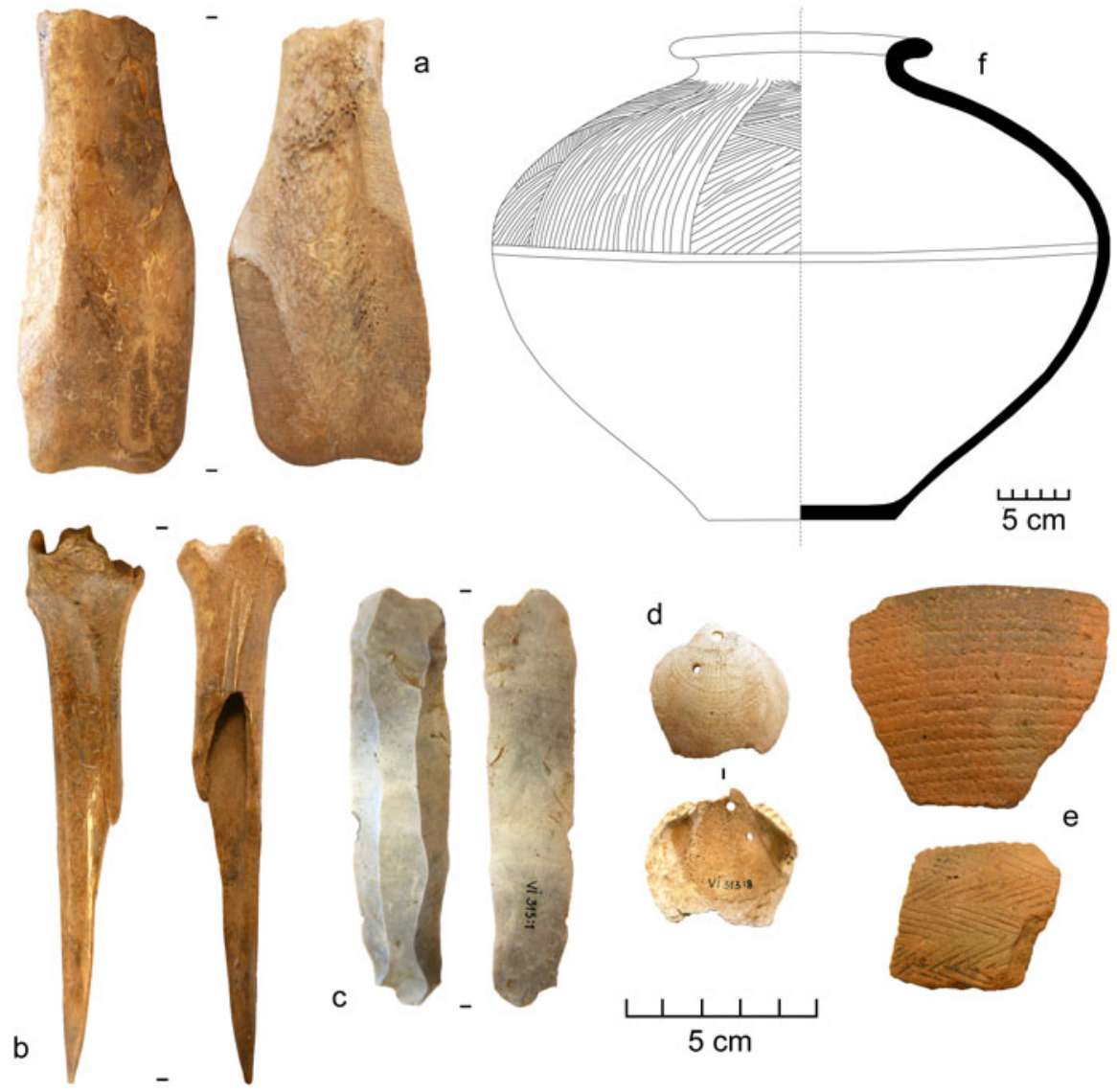

Figure 10. Selected grave goods from a Corded Ware burial in Selgas: a: bone adze; b: bone awl; c: flint knife; d: shell ornament; e: fragments of two Corded Ware beakers; f: reconstructed amphora (after Grasis, 2007: fig. 5). By permission of the Department of Archaeology, National History Museum of Latvia (LNVM VI:313).

cultural layers of the Abora I site (Loze, 1979: 121; Loze \& Eberhards, 2012: tabs. 1-3), like the AMS dates of pottery and food residues (Piličiauskas et al., 2020: 102), cannot be directly connected with the human remains found there, which is also the case with the determinations from Iča, Sārnate, and Vendzavas (Loze, 1992b: tab. 1, 2010: 109; Bērziñ̌s, 2008: tab. 2; Berg-Hansen et al., 2019: tab. 1).

Although most hunter-gatherer burials are located in or near settlements, it is equally difficult to securely link human remains with dateable material even at these sites. Burials, like most Stone Age remains, tend to lie in somewhat elevated locations with mineral soils near (fresh) water bodies and wetlands, which often have been used over long periods. Mobility cycles, hiatuses, and repeated occupation are often difficult to document and may result in a palimpsest. There are also examples where radiocarbon dating has shown considerable age differences between human and habitation remains (Tõrv \& Meadows, 2015). Consequently, stratigraphic sequences give relative, not absolute ages, and contemporaneity inferred from proximity must be proved, not assumed. 
Individual burial customs visible in the material do not date the graves very accurately. Some general trends for certain features, such as the frequency of multiple burials or red ochre (Zagorskis, 1987: 9394; Zagorska, 2006: 101, 2008: 122) are suggested, but numerous long-term trends coupled with significant local and individual variation in the northern huntergatherer burial practices (see Tõrv, 2018; Ahola, 2019) prevent us from using them as strict chronological markers. Typological dating of burial assemblages are also of limited use: most burials contain no grave goods, and, when artefacts are present, they usually provide only broad time frames (see e.g. Zagorska, 2016: 233 for animal tooth pendants and Bērziņš, 2008: 119-20; Loze, $2008 \mathrm{~b}$ for amber items).

In the absence of other indicators, body position served as a central criterion for dating Latvian burials (Macāne, 2007: 52). In particular, all crouched or supine burials with flexed legs were directly attributed to the Corded Ware culture or the Late Neolithic in general (Zagorskis, 1961: 14, 1987: 96; Loze, 1987a, 35, 2006a; Gerhards, 2003: 120). Radiocarbon dating has now shown that the flexed posture is present in the eastern Baltic at least from the sixth millennium BC (Eriksson et al., 2003: 15; Piličiauskas, 2018: 114; Tõrv, 2018: 138; Brinker et al., 2020, 9; see also Larsson, 2000: 92), while also known in later contexts (Gerhards, 2003). Thus, body position alone is insufficient to assign a burial to a given period (see class 2 burials; also Grasis, 2007: 52-53; Piličiauskas, 2018: 114); for example, only three (nos. $88,137,186)$ of the eleven burials earlier associated with the Corded Ware culture at Zvejnieki can demonstrably be linked to it (see also Zagorska, 2006: 103).

The dating of many burials remains broad and tentative. Internal site chronologies cannot be adequately constructed, and, even where detailed spatiotemporal interpretations have been proposed (Abora I, Kreiči, Kvāpāni II; see Zagorskis, 1961, 14; Loze, 1987a, 32-33; 1987b: 6), they cannot be substantiated, as the groupings are based on the depth of the burials, untested spatial patterning, or body position. Similarly, the temporal division based on spatial patterning in Zvejnieki (Zagorskis, 1987: 83-86) does not appear valid in light of the radiocarbon dates obtained (Zagorska \& Larsson, 1994: 8; Zagorska, 2006: 93).

Individual graves from Atkalni I, Sarkani, and Selgas are linked to the Corded Ware culture. At Vendzavas, on the other hand, nothing contradicts the proposed Mesolithic dating (Bērziňš, 2002: 34), although this cannot be confirmed. Burials at Rinnukalns belong to the later fourth millennium $\mathrm{BC}$ (Lübke et al., 2016; Brinker et al., 2020: 9) and Stone Age occupation at the Abora I site dates to the fourth and third millennia $\mathrm{BC}$ (Loze, 1979: 119-21, 1987b: 6). Grave goods (amber items) suggest a similar date, but further cultural attribution is not possible. The fourth-millennium $\mathrm{BC}$ date of the Kreiči settlement (Zagorskis, 1963: 33 ) is not contradicted by the material found in the burials. The assemblage of the Kvāpāni II settlement dates from at least the sixth millennium to the third millennium BC (and even later), with a heavy emphasis on the fourth millennium BC (see Loze, 2015: 71-72). The broad fifth-fourth millennium $\mathrm{BC}$ date suggested by one radiocarbon date is possible for the graves without datable finds but cannot be verified. A sherd of pottery from a grave at Upesgala licis possibly connects the burials to the fourth-millennium $\mathrm{BC}$ context of the settlement site (Loze, 1992a: 66). Finally, Jurkova can only be broadly dated to the Mesolithic-Neolithic period.

Latvian Stone Age hunter-gatherer burial evidence is substantial compared to that from other eastern Baltic regions, and 
the number of finds is paralleled only on the large Russian burial sites, or in southern Scandinavia (e.g. Gurina, 1956; Larsson, 1988; Kostyleva \& Utkin, 2010; Brinch Petersen, 2015). The Corded Ware evidence, on the other hand, is too limited for reaching more than preliminary conclusions.

Almost all known hunter-gatherer burials are situated in the northern and eastern part of Latvia, whereas individual Corded Ware graves and uncertain finds are present in the south and west. This may partially reflect prehistoric preferences and local environments. Inland areas in the north, and especially the east, are characterized by networks of lakes and rivers, a preferred habitat for northern hunterfisher-gatherers. Waterways leading towards the Valday Hills and further east acted as a highway, and promoted the large-scale exchange of flint and amber (Loze, 2008b). The western areas are characterized by undulating lands cut by rivers flowing towards the coast. Corded Ware finds in this part of the country show connections with the territory of present-day Lithuania and further south (Grasis, 2007; Piličiauskas, 2018: 150); Corded Ware material is also found in the east and north, with links to present-day Estonia (Jaanits et al., 1982: 102-17).

While the river Daugava has been a major border dividing the area and placing the west of Latvia into the southern and the east into the northern cultural sphere many times in the past (e.g. Eberts, 1926: 7 ), the current perspective on burials is at least as much an artefact of research history. Nearly all the graves have been discovered by chance and modern land use: the prominence of the Lake Lubāns area is largely the result of extensive rescue excavations, and the enhanced visibility of the Lake Burtnieks region is owed to the well-published studies at Zvejnieki and Rin,nukalns. Interestingly, substantial hunter-gatherer settlement sites (mostly without burials) are known along the less well studied western seaboard (see Vankina, 1970; Loze, 2006b; Bērziņš, 2008).

The era of hunter-fisher-gatherers lasted several millennia, whereas the Corded Ware culture spanned only a few centuries, presumably resulting in fewer burials. Differences in the hunter-gatherer and Corded Ware evidence may owe as much to research priorities as to the scale and nature of past cultural practices. Corded Ware burials occur individually or in small groups outside settlements, as they do in surrounding regions (Loze, 2006a: 312-17; Ahola \& Heyd, 2020: 8788). They are therefore harder to detect archaeologically than hunter-gatherer graves, which are usually encountered in larger groups, characteristically located at settlement sites. Separate hunter-gatherer cemeteries exist only in Kreiči and Zvejnieki, albeit beside settlements.

Settlement site burial is also the most common hunter-gatherer burial practice elsewhere in northern Europe (Zagorskis, 1987: 95-96; Larsson, 1988: 99; Tõrv, 2018: 159; Ahola, 2019: 39). Even if Latvian burial archaeology has traditionally concentrated on the meticulous description of finds and kept interpretation to a minimum, it is proposed that settlement site burials indicate that the dead were kept close to the living (Balodis, 1938: 48). However, the settlement remains and the burials need not always be contemporary; moreover, the proposed custom of burying the dead under the thresholds of houses in Kvāpāni II (Loze, 2008a: 12) cannot be validated. The entanglement of the dead and the living, the mixing of 'the past in the past' (Larsson et al., 2017: 86), is also recognized in the incorporation of occupation layers in the grave fills, or the deliberate intersection of burials and the mixing of older burials in new graves 
(Nilsson Stutz et al., 2013: 1026-27; Tõrv, 2018: 249).

The evidence presented here supports the view that the generally shared ('core') concepts of hunter-gatherer mortuary practices were based on a flat grave tradition (see Zagorskis, 1987: 93; Tõrv, 2018: 257-60; Ahola, 2019: 59). In the Latvian context, the greatest difference between Zvejnieki and other Latvian burial sites is the large quantity of burials associated with settlements (see also Zagorskis, 1987: 95). A near-total absence of ochre, generally scarce grave goods, sitting inhumations, signs of fire, smaller size and shorter period of use distinguish them from Zvejnieki. This may reflect temporal differences or different characteristics connected with cemetery and settlement site burials (see also Ahola, 2017: 210), and at the same time demonstrates the great diversity of Stone Age mortuary practices.

The earliest hunter-gatherer funerary practices recorded in Latvia are paralleled especially in other eastern Baltic region and southern Scandinavia, but also in western Russia. The turn of the fourth millennium $\mathrm{BC}$ marks a transformation, particularly visible in the material culture of the burials (e.g. amber ornaments) and certain practices (e.g. multiple burials, increasing use of ochre). This shift is associated with the appearance of the so-called Comb Ware culture, which influenced vast territories between the Baltic Sea and the Urals. This manifested itself in an increasing eastern influence on the eastern Baltic, also documented in new forms of technology and material culture (e.g. Loze, 2008b; BergHansen et al., 2019: 20), as well as in the aDNA data (Jones et al., 2017: 2-3; Saag et al., 2017: 2189; Mittnik et al., 2018: 8). Nonetheless, the evidence that we have lacks the most typical examples of this burial tradition (Zagorskis, 1987: 85;
Ahola, 2019: 59); rather, it represents parallel or later practices in the area. Despite such changes (or variation) in funerary behaviour during the fourth millennium $\mathrm{BC}$, a clear break with the old customs took place with the arrival of Corded Ware individuals in the early third millennium $\mathrm{BC}$ (Jones et al., 2017: 3; Saag et al., 2017: 2189; Mittnik et al., 2018: 8), introducing a whole new culture of death, shared widely in Europe (see Furholt, 2019).

\section{Conclusion}

Latvian Stone Age burials have been largely approached through the lens of ideal burial presenting conventional inhumation as the only imaginable way to bury a person (e.g. Balodis, 1938: 42, 47); today, this practice can be called 'deviant' (Ahola et al., 2020: 47). Just a fraction of the Stone Age population was inhumed in flat graves, and burial practices must have been diverse, albeit potentially hard to trace archaeologically. Disarticulated human bones, present on all major Latvian hunter-gatherer sites discussed here (see Table 1), may be an indication of some of these alternative ways of handling human remains (Brinch Petersen, 2016, 59; Tõrv, 2018) and require more attention in the future.

Besides the preconceived opinions guiding research, the varying archaeological visibility of different material cultures of death directly affect the representativeness of the material. Modern-day Latvia is no exception. Settlement site burials are generally easier to detect archaeologically than single graves, and rich cemeteries deflect attention from more 'marginal' finds. Preservation conditions and later disturbances may affect a grave's integrity, the uneven geographical distribution of fieldwork and modern land use create biases, the level of recording varies, and what 
becomes 'common knowledge' through publication further filters the data.

Zvejnieki is a unique site with exceptionally well preserved and documented material. It is also published extensively in English, overshadowing other Latvian burial sites. Even though the more than one hundred burials presented here do not directly overturn the story told by Zvejnieki, it introduces spatial depth and nuances previous perspectives. In a wider context, Latvian burials are positioned between various cultural and geographical zones and evidence dynamic and interconnected populations throughout the Stone Age. Much of their value lies in their ability to illustrate the various cultural traditions and their manifestations at different times, reflecting links around the Baltic Basin and with southern Scandinavia but also with the Russian Plain. Presentday Latvia has on many occasions been at the crossroads between northern and southern cultural spheres, with the river Daugava acting as its connecting, or dividing, line.

\section{SuPPlementary Material}

To view supplementary material for this article, please visit https://doi.org/10.1017/ eaa.2020.64.

\section{ACKNOWLEDGements}

This study was supported by the Anérs stiftelsen and Helsinki University Humanities project. The authors wish to thank Normunds Grasis and Ritvars Ritums at the National History Museum of Latvia, and Silvija Tilko and Aigars Vāvere at the Institute of Latvian History for their help with museum collections and archival materials. We also thank four anonymous reviewers for their comments on a previous version of this article.

\section{REFERENCES}

Ahola, M. 2017. The Material Culture of Finnish Stone Age Hunter-Gatherer Burials. Fornvännen, 122: 201-15. Available at: <http://kulturarvsdata.se/raa/ fornvannen/htm1/2017_201>

Ahola, M. 2019. Death in the Stone Age: Making Sense of Mesolithic-Neolithic Mortuary Remains from Finland (ca. 6800 to 2300 cal $B C$ ). Helsinki: University of Helsinki. Available at: <https://helda.helsinki.fi/handle/10138/304712>

Ahola, M. \& Heyd, V. 2020. The Northern Way: Graves and Funerary Practices in Corded Ware Finland. Praehistorische Zeitschrift, 95: 78-111. https://doi.org/10. 1515/1052pz-2020-0002

Ahola, M., Mannermaa, K. \& Kashina, E. 2020. Hunter-Gatherer Prone Burials of the Kubenino Site, NW Russia (c. 5000 cal BC): Normative or Deviant Burials? In: M. Marila, M. Lavento, K. Mannermaa \& M. Ahola, eds. Archaeology and Analogy (Interarcheologia 6). Helsinki: University of Helsinki, pp. 44-64. Available at: $<$ http://www.sarks.fi/interarchaeologia/pdf/ interarchaeologia6.pdf>

Balodis, F. 1938. Senākie laiki: Latviešu senvēsture. In: F. Balodis \& A. Tentelis, eds. Latviešu vèsture, I. Rīga: Valtera un Rapas Akc. Sab. Apgāds, pp. 12-55.

Berg-Hansen, I.M., Damlien, H., Kalniňš, M., Zagorska, I., Schülke, A. \& Bērzinnš, V. 2019. Long-Term Variation in Lithic Technological Traditions and Social Interaction: The Stone Age of the Eastern Baltic (Latvia), 10500-2900 cal BC. Fennoscandia Archaeologica, 36: 6-32. Available at: <http://www.sarks.fi/fa/PDF/ FA36_6.pdf>

Bērzinš, V. 2002. Mezolita apmetne Užavas Vendzavās. Ventspils muzeja raksti, 2: 29-43.

Bērzinšs, V. 2008. Sārnate: Living by a Coastal Lake during the East Baltic Neolithic (Acta Universitatis Ouluensis, B Humaniora 86). Oulu: University of Oulu. Available at: <http://urn.fi/urn:isbn:9789514289415>

Bērzinšs, V., Brinker, U., Klein, C., Lübke, H., Meadows, J., Rudzīte, M., et al. 2014. 
New Research at Rinnukalns, a Neolithic Freshwater Shell Midden in Northern Latvia. Antiquity, 88: 715-32. https://doi. org/10.1017/S0003598X0005064X

Brinch Petersen, E. 2015. Diversity of Mesolitbic Vedbak (Acta Archaeologica, Supplementum 86.1). Oxford: Wiley. https://doi.org/10.1111/j.1600-0390.2015. 12048.x

Brinch Petersen, E. 2016. Afterlife in the Danish Mesolithic: The Creation, Use and Discarding of 'Loose Human Bones'. In: J. Grünberg, B. Gramsch, L. Larsson, J. Orschiedt \& H. Meller, eds. Mesolithic Burials: Rites, Symbols and Social Organisation of Early Postglacial Communities (Tagungen des Landesmuseums für Vorgeschichte Halle, 13/1). Halle: Landesmuseum für Vorgeschichte Halle, pp. 47-62.

Brinch Petersen, E. \& Meiklejohn, C. 2003. Three Cremations and a Funeral: Aspects of Burial Practice in Mesolithic Vedbæk. In: L. Larsson, H. Kindgren, K. Knutsson, D. Loeffler \& A. Åkerlund, eds. Mesolithic on the Move. Oxford: Oxbow Books, pp. 485-93.

Brinker, U., Bērziňš, V., Cerina, A., Gerhards, G., Kalninšs, M., Krause-Kyora, B., et al. 2020. Two Burials in a Unique Freshwater Shell Midden: Insights into Transformations of Stone Age HunterFisher Daily Life in Latvia. Archaeological and Anthropological Sciences, 12: 97. https:// doi.org/10.1007/s12520-020-01049-7

Bugajska, K. 2015. In the Ground or in the Basket? Burial Wrappings from the Stone Age Hunters' Cemetery at Dudka, Masuria, NE-Poland. Novensia, 26: 9-23. Available at: <http://www.novae.uw.edu. pl/rek/novensia/26_Novensia_06.pdf>

Butrimas, A. 2012. Donkalnio ir Spigino mezolito-neolito kapinynai: seniausi laidojimo paminklai Lieturoje. Vilnius: Vilniaus dailès akademijos leidykla.

Cimermane, I. 1967. Pārskats par izrakumiem Krāslavas raj. Ezernieku c.p. Jurkovas s. senvietā 1967. gadā (VIAA: 205). Unpublished report. Riga: Institute of Latvian History.

Cimermane, I. 1968. Aizsardzības izrakumi Ezernieku Jurkovas senvietā. Zinātniskās atskaites sesijas referātu tēzes par arheologu un etnogrāfu 1967. gada pètijumu rezultātiem: 55-57.
Eberts, M. 1923. Tukuma pagats, Matkule, Tojāti (pie Sabiles) (AA: 130). Unpublished report. Riga: National History Museum of Latvia.

Eberts, M. 1926. Jauni ieguvumi Latvijas archaiologijā. Izghîtibas Ministrijas Mènešraksts, 1: 1-8.

Eriksson, G., Lõugas, L. \& Zagorska, I. 2003. Stone Age Hunter-Fisher-Gatherers at Zvejnieki, Northern Latvia: Radiocarbon, Stable Isotope and Archaeozoology Data. Before Farming, 1: 1-26. https://doi.org/ 10.3828/bfarm.2003.1.2

Furholt, M. 2019. Re-Integrating Archaeology: A Contribution to aDNA Studies and the Migration Discourse on the $3^{\text {rd }}$ Millennium BC in Europe. Proceedings of the Prehistoric Society, 85: 115-29. https://doi.org/10.1017/ppr.2019. 4

Gerhards, G. 2003. Saliektie apbedijumi Latvijā no antropoloǵiskā viedokla. Arheolog̣ija un Etnogrāfija, 21: 118-31. https://doi.org/10.22364/aue.21

Grasis, N. 1996. Auklas keramikas kultūras apbedījumi Sarkaņos un Selgās. Zinātniskās atskaites materiāli par arheologu 1994. un 1995. gada pētijumu rezultātiem: 60-65.

Grasis, N. 2007. The Skaistkalnes Selgas Double Burial and the Corded Ware/ Rzucewo Culture: A Model of the Culture and the Development of Burial Practices. Lietuvos Archeologija, 31: 39-70. Available at: $\quad<$ https://talpykla.istorija.lt/jspui/bitstream/99999/1430/1/LA_31_39-70.pdf>

Grünberg, J.M. 2016. Mesolithic Burials: Rites, Symbols and Social Organization of Early Postglacial Communities. In: J. Grünberg, B. Gramsch, L. Larsson, J. Orschiedt \& H. Meller, eds. Mesolitbic Burials: Rites, Symbols and Social Organisation of Early Postglacial Communities (Tagungen des Landesmuseums für Vorgeschichte Halle, 13/1). Halle: Landesmuseum für Vorgeschichte Halle, pp. 13-24.

Gummesson, S., Hallgren, F. \& Kjellström, A. 2018. Keep Your Head High: Skulls on Stakes and Cranial Trauma in Mesolithic Sweden. Antiquity, 92: 74-90. https://doi.org/10.15184/aqy.2017.210

Gurina, N.N. 1956. Oleneostrovskiy mogilnik (Materialy i issledovaniaya po arkheologii SSSR, 47). Moskva: Akademiya nauk. 
Jaanits, L., Laul, S., Lõugas, V. \& Tõnisson, E. 1982. Eesti esiajalugu. Tallinn: Eesti raamat.

Jones, E., Zarina, G., Moiseyev, V., Lightfoot, E., Nigst, P., Manica, A., et al. 2017. The Neolithic Transition in the Baltic was not Driven by Admixture with Early European Farmers. Current Biology, 27: 576-82. https://doi.org/10.1016/j.cub.2016.12.060

Kostyleva, E.L. \& Utkin, A.V. 2010. Neoeneoliticheskie mogil'niki Verkhnego Povolzhy'a $i$ Volgo-Okskogo mezhdurechy'a: Planigraficheskie $i$ kbronologicheskie struktury. Moskva: TAUS.

Kriiska, A. \& Tvauri, A. 2002. Eesti muinasaeg. Tallinn: Avita.

Larsson, L. 1988. Ett fängstsambälle för 7000 ar sedan: Boplatser och gravar i Skateholm. Lund: Signum.

Larsson, L. 2000. Cemeteries and Mortuary Practice in the Late Mesolithic of Southern Scandinavia. In: V. Lang \& A. Kriiska, eds. De temporibus antiquissimis ad honorem Lembit Jaanits (Muinasaja teadus 8). Tallinn: Ajaloo instituut, pp. 81-102.

Larsson, L. 2010. A Double Grave with Amber and Bone Adornments at Zvejnieki in Northern Latvia. Archaeologica Baltica, 13: 80-90. Available at: <http:// briai.ku.1t/downloads/AB/13/13_080090_Larsson.pdf>

Larsson, L. 2016. Some Aspects of Mortuary Practices at the Late Mesolithic Cemeteries at Skateholm, Southernmost Part of Sweden. In: J. Grünberg, B. Gramsch, L. Larsson, J. Orschiedt \& H. Meller, eds. Mesolitbic Burials: Rites, Symbols and Social Organisation of Early Postglacial Communities (Tagungen des Landesmuseums für Vorgeschichte Halle, 13/1). Halle: Landesmuseum für Vorgeschichte Halle, pp. 175-84.

Larsson, L., Nilsson Stutz, L., Zagorska, I., Bērzinšs, V. \& Cerina, A. 2017. New Aspects of the Mesolithic-Neolithic Cemeteries and Settlement at Zvejnieki, Northern Latvia. Acta Archaeologica, 88: 57-93. https://doi.org/10.1111/j.16000390.2017.12177.x

Loze, I. 1979. Pozdniy neolit i rannyaya bronza Lubanskoy ravniny. Rīga: Zinātne.

Loze, I.A. 1987a. Kompleks kul'tury shnnurovoy keramiki na poselenii Kvapani II (Lubanskaya nizina). Latvijas PSR Zinātñu Akadêmijas Vêstis, 7: 23-36.
Loze, I. 1987b. Vēlā neolīta apbedījumi Austrumbaltijā un to kultūras piederība. Arheologija un Etnogrāfija, 15: 5-11. https://doi.org/10.22364/aue.15

Loze, I. 1992a. Arheoloǵiskie pētijumi Upesgala līca neolìta apmetnē. Zinātniskās atskaites sesijas materiāli par arheologu 1990. un 1991. gada pètijumu rezultātiem: 63-66.

Loze, I. 1992b. Corded Pottery Culture in Latvia. In: M. Buchvaldek \& C. Strahm, eds. Schnurkeramik Symposium 1990 (Praehistorica, 19). Praha: Charles University, pp. 313-20.

Loze, I. 1997. The Early Corded Ware Culture in the Territory of Latvia. In: P. Siemen, ed. Early Corded Ware Culture: The A-Horizon: Fiction or Fact? (Arkælogiske Rapporter, 2). Esbjerg: Esbjerg Museum, pp. 135-45.

Loze, I. 2006a. Crouched Burials of the Corded Ware Culture in the East Baltic. In: L. Larsson \& I. Zagorska, eds. Back to the Origin: New Research in the MesolithicNeolithic Zvejnieki Cemetery and Environment, Northern Latvia (Acta Archaeologica Lundensia, Series in $8^{\circ}$, 52). Stockholm: Almqvist \& Wiksell International, pp. 311-26.

Loze, I. 2006b. Neolita apmetnes Ziemelkurzemes kāpās. Rīga: Latvijas Vēstures Institūta Apgāds.

Loze, I. 2008a. Lubāna ezera mitrājs - akmens laikmeta pētniecíbas mikroreǵions Austrumbaltijā: Kemmes keramikas kultūra. Latvijas Vestures Institūta Žurnāls, 3: 5-37.

Loze, I. 2008b. Lubāna ezera mitrāja Neolita dzintars. Rīga: Latvijas Vēstures Institūta Apgāds.

Loze, I. 2010. Iča Neolithic Settlement in the Lake Lubāns Wetland. Archaeologica Baltica, 13: 91-109. Available at: <http:// briai.ku.lt/downloads/AB/13/13_091109_Loze.pdf>

Loze, I. 2015. Lubāna mitrāja apdzīvotība akmens laikmetā. Rēzekne: Rēzeknes Augstskola.

Loze, I. \& Eberhards, G. 2012. Vēlā neolìta Aboras I apmetnes apdzīvotība: Jauni radioaktīvā oglekḷa datējumi Lubāna mitrājā. Latvijas Zinātnu Akadêmijas Vestis, 66: 26-38. Available at: <http:// archive.lza.lv/LZA_VestisA/66_5-6/ 3_IlzeBirutaLoze_GuntisEberhards.pdf> 
Lübke, H., Brinker, U., Meadows, J., Bērziņš, V. \& Zagorska, I. 2016. New Research on the Human Burials of Rinnnukalns, Latvia. In: J. Grünberg, B. Gramsch, L. Larsson, J. Orschiedt \& H. Meller, eds. Mesolitbic Burials: Rites, Symbols and Social Organisation of Early Postglacial Communities (Tagungen des Landesmuseums für Vorgeschichte Halle, 13/1). Halle: Landesmuseum für Vorgeschichte Halle, pp. 241-57.

Macāne, A. 2007. Akmens laikmeta pētniecības vēsture Latvijā no 1918.-2005. gadam (unpublished BA dissertation, University of Latvia, Riga).

Meadows, J., Bērziņš, V., Brinker, U., Lübke, H., Schmölcke, U., Staude, A. et al. 2016. Dietary Freshwater Reservoir Effects and the Radiocarbon Ages of Prehistoric Human Bones from Zvejnieki, Latvia. Journal of Archaeological Science: Reports, 6: 678-89. https://doi.org/10.1016/j.jasrep. 2015.10.024

Meadows, J., Bērziņš, V., Legzdina, D., Lübke, H., Schmölcke, U., Zagorska, I. \& Zarina, G. 2018. Stone-Age Subsistence Strategies at Lake Burtnieks, Latvia. Journal of Archaeological Science: Reports, 17: 992-1006. https://doi.org/10.1016/j. jasrep.2016.03.042

Meadows, J., Lübke, H., Zagorska, I., Bērzin̦š, V., Cerina, A. \& Ozola, I. 2014. Potential Freshwater Reservoir Effects in a Neolithic Shell Midden at Rinnukalns, Latvia. Radiocarbon, 56: 823-32. https:// doi.org/10.2458/56.16950

Mittnik, A., Wang, C.-C., Pfrengle, S., Daubaras, M., Zarina, G., Hallgren, F., et al. 2018. The Genetic Prehistory of the Baltic Sea Region. Nature Communications, 9: 442. https://doi.org/10.1038/s41467018-02825-9

Nilsson, L. 2007. Setting it Straight: A ReAnalysis of the Mesolithic Barum Burial According to the Principles of Anthropologie 'de terrain'. Lund Archaeological Review, 11-12 (2005-2006): 37-46. Available at: <https://journals.lub. lu.se/lar/article/view/21780/19613>

Nilsson Stutz, L. 2006. Unwrapping the Dead: Searching for Evidence of Wrapping in the Mortuary Practices at Zvejnieki. In: L. Larsson \& I. Zagorska, eds. Back to the Origin: New Research in the Mesolithic-Neolithic Zvejnieki Cemetery and Environment, Northern Latvia (Acta Archaeologica Lundensia, Series in $8^{\circ}$, 52). Stockholm: Almqvist \& Wiksell International, pp. 217-33.

Nilsson Stutz L., Larsson, L. \& Zagorska, I. 2013. The Persistent Presence of the Dead: Recent Excavations at the Huntergatherer Cemetery at Zvejnieki (Latvia). Antiquity, 87: 1016-29. https://doi.org/10. 1017/S0003598X00049838

Ozolinšs, F. 1926. Jelgavas apr. Dobeles p. Bālu kapulauks (AA: 87). Unpublished report. Riga: National History Museum of Latvia.

Petrenko, V. \& Virse, I. 1990. Grobinas Atkalnu un Grobinas Priediena I kapulauks. Zinātniskās atskaites sesijas materiāli par arheologu un etnogrāfu 1988. un 1989. gada pētijumu rezultātiem: 125-26.

Piličiauskas, G. 2018. Virvelines keramikos kultūra Lieturoje 2800-2400 cal BC. Vilnius: Lietuvos istorijos institutas.

Piličiauskas, G., Kluczynska, G., Kisielienè, D., Skipityte, R., Peseckas, K., Matuzevičiūtè, S., et al. 2020. Fishers of the Corded Ware Culture in the Eastern Baltic. Acta Archaeologica, 91: 95-120. https://doi.org/10.1111/j.1600-0390.2020. 12223.x

Saag, L., Varul, L., Lyn Scheib, C., Stenderup, J., Allentoft, M.E., Saag, L., et al. 2017. Extensive Farming in Estonia Started Through a Sex-biased Migration from the Steppe. Current Biology, 27: 2185-93. https://doi.org/10.1016/j.cub. 2017.06.022

Sievers, C.G. 1875. Ein normännisches Schiffsgrab bei Ronneburg und die Ausgrabung des Rinnehügels am Burtneck-See (Livland). Zeitschrift für Ethnologie, 7: 214-23. Available at: <https://www.jstor.org/stable/23029131>

Šnore, E. 1935. Pārskats par pārbaudes izrakumiem Kuldīgas apr. Zvārdes pag. Grīnertos videjā dzelzs laikmeta kapulaukā 1935. gadā (VIAA: 1036). Unpublished report. Riga: Institute of Latvian History.

Šnore, R. 1938. Latvijas senvēstures pētišanas darbi valsts pastāvēšanas 20 gados. Senatne un Māksla, 4: 39-96.

Stubavs, A. 1980. Krīgānu arheologiskās ekspedīiijas darbs 1979. gadā. Zinātniskās atskaites sesijas materiāli par arheologu un etnogrāfu 1979. gada pētijumu rezultātiem: 86-91. 
Šturms, E. 1927a. Akmens laikmets Latvijā II. Savrupatradumi un kultūras raksturojums (Latvijas vēstures pirmavoti, 6). Rīga: Izdevēja Latvijas skolotāju savienība.

Šturms, E. 1927b. Akmens laikmets Latvijā I. Dzīvesvietas (Latvijas vēstures pirmavoti, 5). Rīga: Izdevēja Latvijas skolotāju savienība.

Šturms, E. 1946. Die erste schnurkeramische Siedlung in Lettland (Contributions of Baltic University 17). Hamburg: Broschek.

Šturms, E. 1970. Die steinzeitlichen Kulturen des Baltikums (Antiquitas, 3.9). Bonn: Rudolf Habelt.

Tõrv, M. 2018. Persistent Practices: A Multidisciplinary Study of Hunter-Gatherer Mortuary Remains from c. 6500-2600 cal. $B C$, Estonia (Untersuchungen und Materialien zur Steinzeit in SchleswigHolstein und im Ostseeraum, 9). Kiel/ Hamburg: Wachholtz.

Tõrv, M. \& Meadows, J. 2015. Radiocarbon Dates and Stable Isotope Data from the Early Bronze Age Burials in Riigiküla I and Kivisaare Settlement Sites, Estonia. Radiocarbon, 57: 645-56. https://doi.org/ 10.2458/azu_rc.57.18459

Vankina, L. 1968. Ezernieku c. Jurkovas s. Broča mājas. Pārskats par 1968. g. izrakumiem neolìta kapulaukā un apmetnē (VIAA: 181). Unpublished report. Riga: Institute of Latvian History.

Vankina, L. 1970. Torfyanikovaya stoyanka Sarnate: Sarnates purva apmetne. Riga: Zinatne.

Vankina, L. \& Cimermane, I. 1969. Izrakumi Jurkovas senvietā 1968.g. Zinātniskās atskaites sesijas referātu tēzes par arheologu, antropologu un etnogrāfu 1968. gada pētijumu rezultātiem: 57-59.

Zagorska, I. 2006. Radiocarbon Chronology of the Zvejnieki Burials. In: L. Larsson \& I. Zagorska, eds. Back to the Origin: New Research in the Mesolithic-Neolithic Zvejnieki Cemetery and Environment, Northern Latvia (Acta Archaeologica Lundensia, Series in $8^{\circ}$, 52). Stockholm: Almqvist \& Wiksell International, pp. 91-114.

Zagorska, I. 2008. The Use of Ochre in Stone Age Burials of the East Baltic. In: F. Fahlander \& T. Oestigård, eds. The Materiality of Death: Bodies, Burials, Beliefs (British Archaeological Reports International Series, 1768). Oxford: Archaeopress, pp. 115-24.
Zagorska, I. 2016. Mesolithic Burial Traditions in Latvia: A Case Study from Zvejnieki Burial Ground. In: J. Grünberg, B. Gramsch, L. Larsson, J. Orschiedt \& H. Meller, eds. Mesolithic Burials: Rites, Symbols and Social Organisation of Early Postglacial Communities (Tagungen des Landesmuseums für Vorgeschichte Halle, 13/1). Halle: Landesmuseum für Vorgeschichte Halle, pp. 225-39.

Zagorska, I. \& Larsson, L. 1994. New Data on the Chronology of the Zvejnieki Stone Age Cemetery. Mesolithic Miscellany, 15: 3-10. Available at: <https://archaeologydataservice.ac.uk/archives/view/mesomisc_na_2006/>

Zagorska, I., Meadows, J. \& Iršenas, M. 2018. New Dates from Zvejnieki Burial Ground Graves with Anthropomorphic and Zoomorphic Figurines. Archaeologica Baltica, 25: 100-24. http://doi.org/10. 15181/ab.v25i0.1833

Zagorskis, F. 1961. Kreiču neolìta kapulauks. Arheologija un Etnogrāfija, 3: 3-18. https:// doi.org/10.22364/aue.03

Zagorskis, F. 1963. Kreiču neolīta apmetne. Latvijas PSR Zinātnu Akadèmijas Véstis, 4: 23-35.

Zagorskis, F. 1987. Zvejnieku akmens laikmeta kapulauks. Rīga: Zinātne.

Zagorskis, F. 2004. Zvejnieki (Northern Latvia) Stone Age Cemetery (British Archaeological Reports International Series, 1292). Oxford: Archaeopress.

\section{Biographical Notes}

Aija Macāne is a doctoral student at the Department of Historical Studies, University of Gothenburg (Sweden). Specialized in archaeology and zooarchaeology, her dissertation examines animal bones and tooth pendants from hunterfisher-gatherer burials in the Baltic Sea region and northern Europe. Her principal interest is in Stone Age burial practices and Holocene hunter-gatherer relationships with the animal world and the surrounding environment. 
Address: Department of Historical Studies, University of Gothenburg, Box 200, 40530 Gothenburg, Sweden. [email: aija. macane@gu.se]. ORCID: 0000-00028839-6438.

Kerkko Nordqvist is a postdoctoral researcher at the Faculty of Arts, University of Helsinki (Finland). He specializes in the Stone Age archaeology of northern Europe, particularly the eastern Baltic region and north-western Russia. His current research interests include the adoption and spread of technologies and material cultures among hunter-fisher-gatherer societies during the sixth-third millennia BC. He also conducts research examining the development of the Corded Ware complex, its impact, and interactions in this zone.

Address: Faculty of Arts, University of Helsinki, P.O. Box 4, 00014 Helsingin yliopisto, Finland. [email: kerkko.nordqvist@helsinki.fi]. ORCID: 0000-00018696-1707.

\section{Plus que Zvejnieki : un tour d'horizon des sépultures préhistoriques de Lettonie}

La célèbre nécropole de Zvejnieki est avec plus de 330 sépultures un des plus grands sites funéraires de chasseurs-cueilleurs en Europe septentrionale, éclipsant les plus que 115 autres sépultures reparties sur une dizaine de sites en Lettonie. Ici, les auteurs présentent une première mise au point concernant ces dernières en traitant l'histoire des recherches, les traits caractéristiques et le contenu de ces tombes. Ils considèrent les problèmes liés à la chronologie des sépultures de l'âge de la Pierre en Lettonie dans un contexte régional plus large. La plupart des sépultures sont celles de chasseurs-cueilleurs mais quelques exemples appartiennent à la culture de la céramique cordée. Ce survol permet d'approfondir nos connaissances sur l'âge de la Pierre en Lettonie et met en lumière les diverses pratiques funéraires des chasseurscueilleurs en Baltique orientale. Translation by Madeleine Hummler

Mots clés: âge de la Pierre, chasseurs-cueilleurs, pratiques funéraires, sépultures sur sites d'habitat, sépultures fléchies, Lettonie

\section{Mehr als Zvejnieki: die lettischen steinzeitlichen Gräber in Übersicht}

Das bekannte Gräberfeld von Zvejnieki ist mit 330 Gräber eines der größten Jäger und Sammler Gräberfelder in Nordeuropa und stellt die mehr als 115 anderen Bestattungen, welche in etwa zehn Fundorten in Lettland entdeckt worden sind, in den Schatten. Dieser Artikel gibt eine erste Übersicht über die Forschungsgeschichte, Eigenschaften und Inhalt von diesen anderen Gräbern. Die Autoren betrachten die Zeitstellung der lettischen steinzeitlichen Gräber und erwägen sie in ihrem weiteren regionalen Zusammenhang. Die Mehrzahl sind Jäger- und Sammler-Bestattungen, aber einige gehören zur Schnurkeramik-Kultur. Diese Studie erweitert unser Verständnis der lettischen steinzeitlichen Gräber und verdeutlicht die Vielfalt der Bestattungssitten der Jäger und Sammler im ostbaltischen Bereich. Translation by Madeleine Hummler

Stichworte: Steinzeit, Jäger und Sammler, Bestattungssitten, Bestattungen auf Siedlungen, Höckerbestattungen, Lettland 